\title{
THE DARK-SIDE OF COOPETITION: WHEN COLLABORATING WITH COMPETITORS IS HARMFUL FOR COMPANY PERFORMANCE
}

\begin{abstract}
Purpose - Coopetition is the interplay between cooperation and competition, involving organisations sharing resources and capabilities with rival entities. Earlier work has suggested that coopetition has a linear (positive) relationship with company performance, with scarce considerations towards whether this link could have a diminishing-returns effect. Thus, this paper examines the non-linear (quadratic) relationships between coopetition and three performance outcomes. Using resourcebased theory and the relational view, this study is designed to evaluate the dark-side of coopetition, in terms of identifying situations when such activities can be harmful for company performance.
\end{abstract}

Design/methodology/approach - Survey data were collected from a sample of 101 vineyards and wineries in New Zealand. After purifying the measures through a series of multivariate statistical techniques, the research hypotheses and control paths were tested through hierarchical regression. Furthermore, the statistical data passed all major assessments of reliability and validity (including common method variance).

Findings - Coopetition was found to have non-linear (quadratic) relationships with customer satisfaction performance, market performance, and financial performance. These results indicate that while coopetition provides organisations with new resources, capabilities, and opportunities, there are some dark-sides of coopetition activities. With "too little" coopetition, firms might struggle to survive within their markets, with an insufficient volume of resources and capabilities. With "too much" coopetition, companies could experience increased tensions, potentially lose intellectual property, and dilute their competitive advantages. Such negative outcomes could harm their performance in several capacities.

Practical implications - Firms should appreciate that coopetition is a competitive strategy. In other words, regardless of how much collaboration occurs, coopetition partners are still competing entities. It is recommended that organisations should strive to engage in an "optimal-level" of coopetition, as "too little" or "too much" of such strategies can be harmful for various types of company performance. To mitigate some of the dark-sides of coopetition, businesses should attempt to utilise all the benefits of collaborating with competitors (i.e., accessing new resources, capabilities, and opportunities), but at the same time, not become dependent on rivals' assets.

Originality/value - This current article develops and tests a framework examining the non-linear (quadratic) linkages between coopetition and multiple assessments of company performance. It highlights the benefits and drawbacks of businesses sharing resources and capabilities with their competitors. Contrary to prior studies in the business-to-business marketing literature, the results signify that firms need to engage in an "optimal-level" of coopetition to minimise certain dark-sides, such as reduced company performance. After providing some practitioner implications, this paper ends with a series of limitations and avenues for future research.

Keywords - Coopetition, company performance, dark-side, resource-based theory, relational view, business-to-business marketing.

Classification - Research paper. 


\section{Introduction}

Coopetition (or coopetition activities) is a fundamental business-to-business marketing strategy (Rusko, 2011; Dahl, 2014; Bouncken et al., 2015; Leite et al., 2018). It is comprised of cooperative and competitive dimensions that help organisations to acquire new resources, capabilities, and opportunities that they would not have access to under individualistic business models - where coopetition does not occur (Ritala et al., 2014; Gnyawali et al., 2016; Arslan, 2018; Velu, 2019). In terms of its seminal definition, coopetition is "a dynamic and paradoxical relationship, which arises when two companies cooperate in some areas (such as strategic alliances), but simultaneously compete in other areas" (Bengtsson and Kock, 2000, p. 411). As coopetition activities are intended to provide firms with new ways to compete within their competitive business environments, it is unsurprising that scholars have invested a large volume of research towards understanding the relationship between coopetition and company performance (Bengtsson and Kock, 1999; Luo, 2007; Bouncken and Kraus, 2013; Crick and Crick, 2016a; Sanou et al., 2016; Velu, 2016; Felzensztein et al., 2018; Gnyawali and Charleton, 2018; Tidstrom et al., 2018).

Despite numerous investigations in the business-to-business marketing literature having explored the relationship between coopetition and company performance, such research is underpinned by a key (and arguably limited) assumption. That is, businessto-business marketing scholars have predominately highlighted that collaborating with competitors (e.g., sharing resources and capabilities) leads to higher-levels of company performance, with minimal considerations towards a potential diminishingreturns effect (Rindfleisch and Moorman, 2003; Fang, 2006; Ritala, 2012; Bengtsson and Raza-Ullah, 2016; Crick, 2018a). In other words, academic and practical recommendations have encouraged firms to engage in increased forms of coopetition, 
as such activities are likely to improve their performance. Alternatively, very few studies have suggested that the relationship between coopetition and company performance could be non-linear (quadratic) (Luo et al., 2007; Ang, 2008; Crick, 2019). This is a critical issue, since it could be that coopetition is a performance-driving activity, but only up to a certain point, for which "too little" and "too much" coopetition could be harmful for company performance ${ }^{1}$.

Additionally, the business-to-business marketing literature has examined how coopetition activities can yield inter-firm tensions between competing organisations. Tensions have included conflict and power imbalances, where the paradoxical forces of cooperativeness and competitiveness cannot be differentiated (Tidstrom, 2009; Park et al., 2014; Raza-Ullah et al., 2014; Mattsson and Tidstrom, 2015; Bouncken et al., 2016; Raza-Ullah, 2019). Yet, these negative aspects of coopetition activities have scarcely been attributed to the potential non-linear (quadratic) link with company performance. This means that research is needed to better-understand the underlying mechanisms behind this diminishing-returns effect. Company performance can be conceptualised and operationalised in numerous capacities (Ray et al., 2004; Katsikeas et al., 2016). Thus, it is of interest to consider the multiple performance outcomes of coopetition, so that recommendations can be made to scholars and practitioners about what assessments of performance are most likely to be affected by collaborating with competitors. This is especially important because firms have varied performance objectives (Crick and Crick, 2015; Crick et al., 2018), meaning that coopetition could be better-linked to certain measures over others.

\footnotetext{
1 It is appreciated that non-linear (quadratic) effects can exist in different respects. In this current study, the non-linear (quadratic) relationship between coopetition and three assessments of company performance was conceptualised as having an inverted U-shaped association (as opposed to U-shaped).
} 
Hence, the objective of this investigation is to examine the non-linear (quadratic) relationships between coopetition and customer satisfaction performance, market performance, and financial performance (measures guided by Hooley et al., 2005; Vorhies and Morgan, 2005; Morgan et al., 2009). To achieve this research objective, resource-based theory and the relational view were utilised. Resource-based theory explained how firms can employ their competitors' resources and capabilities with their own assets (Combs and Ketchen Jr., 1999; Hannah and Eisenhardt, 2018). The relational view supplemented these conceptualisations to understand how the quality of inter-firm relationships can affect the performance outcomes of coopetition (Dyer and Singh, 1998; Lavie, 2006; Dyer et al., 2018). Consequently, this article is divided into the following core sections. First, the framing literature is reviewed. Second, the conceptual framework is presented, with the research hypotheses and control paths. Third, the adopted methodology is described. Fourth, the empirical results are outlined. Fifth, the discussion links the empirical results to the extant business-to-business marketing literature. Sixth, the paper is concluded, alongside some practitioner implications and a series of limitations and avenues for future research.

\section{Framing literature}

\section{Resource-based theory and the relational view}

Resource-based theory examines the connection between an organisation's tangible and intangible assets (resources and capabilities respectively) and company performance (Barney, 1991; Tzokas and Saren, 2004; O'Cass et al., 2015; Cortez and Johnston, 2019). The resource-based view has been linked to the coopetition construct to highlight that by collaborating with rival entities, businesses can acquire new resources and capabilities that they would not be able to access under 
individualistic business models (Combs and Ketchen Jr., 1999; Hannah and Eisenhardt, 2018). However, the resource-based view only informs business-tobusiness marketing scholars of a proportion of the issues associated with the interplay between cooperation and competition. That is, resource-based theory has been extended through the relational view to account for how the quality of inter-firm relationships can affect company performance (Lavie, 2006). The relational view considers how businesses need to trust the stakeholders (e.g., competitors) that they are collaborating with and should work with those that can yield mutually-beneficial outcomes (Dyer and Singh, 1998; Coviello and Brodie, 2001; Dyer et al., 2018).

Crick (2019) integrated the relational view and resource-based theory to conceptualise the nature of the relationship between coopetition and company performance. In terms of the non-linear (quadratic) link, Crick (2019) proposed that the resource-based view explains the positive aspects of coopetition, including the prior-mentioned access to new resources and capabilities (as well as opportunities). However, Crick (2019) argued that the relational view explains that if organisations work with untrustworthy competitors, they can experience a range of negative (performance-harming) outcomes, like losing intellectual property, diluting their competitive advantages, and yielding tensions with their rivals (as per Tidstrom, 2009; Ritala and HurmelinnaLaukkanen, 2013; Raza-Ullah et al., 2014; Tidstrom et al., 2018; Raza-Ullah, 2019). In this current study, the relational view and resource-based theory are integrated to explore the underlying mechanisms behind the non-linear (quadratic) relationship between coopetition and company performance. This helps to evaluate some of the dark-sides of firms collaborating with their competitors. Plus, utilising resource-based theory and the relational view allowed this article to respond to recent calls for research 
to appreciate the complexities of the coopetition - company performance relationship (see Shu et al., 2017; Hoffmann et al., 2018).

\section{Assessments of company performance}

Under the relational view and resource-based theory, company performance has been conceptualised and operationalised in numerous capacities, with scholars examining outcomes, such as competitive advantages, collaborative advantages, market-level survival, and sales performance (Kanter, 1994; Hunt and Morgan, 1995; Mohr and Sengupta, 2002; Hunt and Derozier, 2004; Peters et al., 2010; Dyer et al., 2018; Jin and Cho, 2018). In this current study, company performance is explored in three respects. First, customer satisfaction performance is the extent to which firms have satisfied their customers' wants and needs (Vorhies and Morgan, 2005). Second, market performance is the degree to which organisations have grown within their markets (Hooley et al., 2005). Third, financial performance is the level of financial success that entities have secured within their markets (Morgan et al., 2009). These outcomes were anticipated to encapsulate the main types of company performance (Ray et al., 2004; Katsikeas et al., 2016). Also, these outcomes link with the relational view and resource-based theory (Dyer and Singh, 1998; Barney et al., 2001; Hooley et al., 2005; Vorhies and Morgan, 2005; Lavie, 2006; Morgan et al., 2009).

\section{The origins of the coopetition construct}

Coopetition was incorporated into the business-to-business marketing literature in the 1990s. During these early years, there were different viewpoints on how the coopetition construct should be investigated. Brandenburger and Nalebuff (1996) conceptualised coopetition as being an organisation-wide mind-set associated with managers and functional-level employees believing in the importance of collaborating with 
competitors. Bengtsson and Kock (1999) conceptualised the coopetition construct as a set of firm-level behaviours linked with companies cooperating with their rivals to achieve mutually-beneficial outcomes, like improved value chains. Since then, coopetition has been primarily studied from a behavioural angle pertaining to firms collaborating with their competitors through the sharing of resources and capabilities (Felzensztein et al., 2012; Dahl, 2014; Velu, 2016; Shu et al., 2017; Chou and Zolkiewski, 2018). Regardless of how coopetition is studied, it is comprised of the interplay between cooperation and competition (Bengtsson and Raza-Ullah, 2016; Gnyawali and Charleton, 2018). This means there will always be some form of rivalry driving these strategies (Bouncken et al., 2015; Cui et al., 2018).

Resource-sharing activities include companies lending and borrowing tangible assets, such as equipment that is expensive to purchase, but can be accessed at minimal inconvenience from rival entities (Granata et al., 2018). Capability-sharing activities concern businesses sharing intangible assets, including knowledge and experience with their competitors (Rusko, 2011). Further, coopetition has been explored in great depth in regional clusters (e.g., agricultural markets), whereby, rivals simultaneously cooperate and compete to obtain mutually-beneficial performance outcomes (Felzensztein and Deans, 2013; Geldes et al., 2017; Felzensztein et al., 2018). Indeed, coopetition has been studied in a range of industries and countries, like automotive manufacturers (Andersson and Nyberg, 1998; Akpinar and Vincze, 2016), tourism service providers (Czakon and Czernek, 2016), alcohol producers (Felzensztein et al., 2014), high-tech firms (Gnyawali and Park, 2011), and sporting organisations (Crick and Crick, 2016a). That is, the business-to-business marketing literature has uncovered several issues associated with the dimensions, antecedents, and consequences of behavioural forms of coopetition (Luo et al., 2007; Ritala, 2012; 
Bouncken and Kraus, 2013; Ritala et al., 2014; Gnyawali et al., 2016; Shu et al., 2017; Bouncken et al., 2018).

Developments to coopetition in the business-to-business marketing literature

Over the last five years, there have been several developments to coopetition in the business-to-business marketing literature. In 2014, a special issue of Industrial Marketing Management was published on the state of coopetition-based knowledge and some directions for future research. In their guest editorial, Bengtsson and Kock (2014, p. 180) re-defined coopetition as "a paradoxical relationship between two or more actors, regardless of whether they are involved in horizontal or vertical relationships, simultaneously in cooperative and competitive interactions." Importantly, Bengtsson and Kock (2014) highlighted that coopetition activities can involve multiple rivals sharing resources and capabilities, as opposed to their seminal definition, which restricted coopetition to two competing firms (see Bengtsson and Kock, 2000). This special issue explored some of the negative aspects of the coopetition construct, such as the tensions that might exist when two or more rivals collaborate, as well as the competitive dynamics that exist in coopetition-oriented strategies (e.g., Park et al., 2014; Raza-Ullah et al., 2014; Ritala et al., 2014; Tidstrom, 2014). Thus, it is of interest to expand upon these conceptualisations with more depth on the dark-side of coopetition and the potential diminishing-returns effect with company performance (extending the work of Luo et al., 2007; Ang, 2008; Crick, 2019).

In 2016, Industrial Marketing Management published a special section on coopetition, exploring issues, like how organisations can manage and implement these strategies (Akpinar and Vincze, 2016; Bengtsson et al., 2016; Czakon and Czernek, 2016; Strese et al., 2016). Hence, there is more evidence that the business-to-business marketing 
literature has shifted its focus towards the ways that companies can execute coopetition activities and navigate the paradoxical forces of cooperativeness and competitiveness. In 2018, the Strategic Management Journal published a special issue on coopetition (edited by Hoffmann et al., 2018). In this special issue, several articles examined the complexities of the relationship between coopetition and company performance, including some of the tensions associated with the interplay between cooperation and competition (Arslan, 2018; Cui et al., 2018; Hannah and Eisenhardt, 2018). Consequently, there is all the more reason that research should be directed towards not just the non-linear (quadratic) relationship between coopetition and company performance, but also, the underlying mechanisms behind this link (extending Luo et al., 2007; Ang, 2008; Crick, 2019). In turn, this research should examine the dark-side of the coopetition construct.

Recently, research has been conducted on the multiple-levels of coopetition activities (Bengtsson et al., 2016; Tidstrom and Rajala, 2016). Luo et al. (2006) explored how coopetition can occur between the departments of large corporations (as per Luo, 2005; Gnyawali and Park, 2011; Ranganathan et al., 2018). They suggested that certain departments can perceive other areas of a business as being their competitors, depending on factors, like the volume of resource investments made to each function. As another illustration, Bengtsson and Raza-Ullah (2016) conducted a systematic literature review and found that there are three schools-of-thought within this body of knowledge. The "activity school" is a one-to-one direct relationship between competing organisations, the "actor school" is the view that coopetition occurs in a broader network context, with various stakeholders, and the "blended school" is a multi-level view of the coopetition construct, in which such strategies are implemented differently by the stakeholders involved. Bengtsson and Raza-Ullah's (2016) paper has been 
supplemented by other work related to the stakeholder-wide view of coopetition (Akpinar and Vincze, 2016; Bengtsson et al., 2016).

There have been other developments to coopetition throughout the business-tobusiness marketing literature. For instance, Crick and Crick (2019) developed and validated a multi-dimensional measure of coopetition, namely, the COOP scale. Using data from sporting clubs in New Zealand, they found that coopetition is a threedimension construct. First, local-level coopetition is where organisations collaborate with their competitors within a close geographic proximity (see Geldes et al., 2017; Felzensztein et al., 2018; Granata et al., 2018). Second, national-level coopetition is where companies share resources and capabilities with their rivals across different regions, but within the same country (linking with Felzensztein and Deans, 2013; Gnyawali and Charleton, 2018). Third, organisation-level coopetition is where firms cooperate with rival entities across various product-markets (including with indirect competitors), regardless of their region (as per Crick and Crick, 2016a; Virtanen and Kock, 2016). The theory underpinning the COOP scale highlights that coopetition is a multi-level construct, for which Crick and Crick (2019) provided a different viewpoint to other business-to-business marketing papers (e.g., Luo et al., 2006; Gnyawali and Park, 2011; Bengtsson and Kock, 2014; Bengtsson and Raza-Ullah, 2016; Ranganathan et al., 2018).

\section{The dark-side of coopetition}

In the broader marketing literature, a dark-side is a construct or situation that is actively bad for organisations (Mick, 1996; Dant and Gleiberman, 2011; Daunt and Greer, 2017). In business-to-business marketing relationships, there will always be negative aspects pertaining to working with partners with varied objectives, close inter-personal 
ties, and vague contracts (Abosag et al., 2016). If dark-sides exist within business-tobusiness marketing activities (including coopetition), there can be uncertainty and distrust between the firms involved - yielding reductions in company performance (see Grayson and Ambler, 1999; Tidstrom, 2009; Fang et al., 2011; Raza-Ullah et al., 2014; Crick et al., 2019a). In this current study, the dark-side of coopetition is explored by focusing on the non-linear (quadratic) relationship between such activities and company performance (building upon Luo et al., 2007; Ang, 2008; Crick, 2019). In doing so, this investigation evaluates whether "too little" and "too much" coopetition is harmful for company performance. Thus, situations can be identified when coopetition is actively bad for organisations - and the underlying mechanisms behind the diminishing-returns effect can be better-understood.

Before the dark-side of coopetition is explored, it is important to review the earlier work associated with the dark-side of commercial relationships throughout the broader marketing literature. In a business-to-consumer marketing context, authors have examined the dark-side of value co-creation, namely, value co-destruction (see Ple and Chumpitaz Caceres, 2010; Echeverri and Skalen, 2011; Skalen et al., 2015; Chowdhury et al., 2016; Zhang et al., 2018). Value co-creation is where businesses cooperate with their customers to improve their service quality, offerings, and overall experience to create a degree of customer value that out-performs industry rivals (Vargo and Lusch, 2004; Payne et al., 2008; Edvardsson et al., 2011; Ranjan and Read, 2016; Sinkovics et al., 2018). Value co-destruction is where firms misuse customers' efforts, resources, and experiences and create negative outcomes for the parties involved - counter-productive to the purpose of value co-creation (Smith, 2013; Heidenreich et al., 2015; Daunt and Harris, 2017). In fact, value co-destruction (and 
associated service issues) can be driven by dysfunctional employees and/or customers (Patterson and Baron, 2010; Kim et al., 2019).

If firms engage in value co-destruction (instead of value co-creation), it could be difficult to implement service recovery strategies to mitigate the damage from such poorquality business-to-consumer marketing relationships (Caru and Cova, 2015). Following on, value co-creation (and value co-destruction) has been incorporated into the business-to-business marketing literature (Gronroos, 2009; Komulainen, 2014; Peters et al., 2018; Cabiddu et al., 2019). For instance, Chowdhury et al. (2016) linked inter-firm tensions to some of the dark-sides of value co-creation. They argued that when two or more industry rivals are working together to create a superior experience and service quality for their customers, the companies involved could witness problems pertaining to the power exerted by certain parties. They also noted the potential for opportunistic behaviours related to firms misjudging the interplay between cooperation and competition. Interestingly, Chowdhury et al.'s (2016) paper links with some of the existing research on the dark-sides of coopetition, whereby, if rivals cannot differentiate between the paradoxical forces of cooperativeness and competitiveness, there can be a range of negative outcomes, such as tensions and lower-levels of performance (Fang, 2006; Tidstrom, 2009 Gnyawali et al., 2016; Crick et al., 2019a; Raza-Ullah, 2019).

While the dark-side of value co-creation was used to position this study's overall contribution, it was of more interest to examine the core areas pertaining to the harmful aspects of coopetition. Several articles have explored the negative aspects of coopetition strategies. In addition to noting the need to navigate the paradoxical forces of cooperativeness and competitiveness (Raza-Ullah et al., 2014; Mattsson and Tidstrom, 2015; Gnyawali et al., 2016), other investigations have outlined the negative 
outcomes of poorly-managed coopetition strategies. Such negative outcomes surround inter-firm conflict and power imbalances (tensions), opportunistic behaviours, losing intellectual property, and diluting competitive advantages (Tidstrom, 2009; Ritala and Hurmelinna-Laukkanen, 2013; Tidstrom et al., 2018; Raza-Ullah, 2019). These problems can reduce several assessments of company performance (Luo et al., 2007; Ang, 2008; Crick, 2019). Despite the dark-side of coopetition being an emerging strand of knowledge, it is relatively under-researched compared to the positive aspects of such strategies. The non-linear (quadratic) links between coopetition and three performance outcomes should uncover the dark-side of such strategies.

Also, the dark-side of inter-firm relationships has been studied in other areas of the business-to-business marketing literature. Grandinetti (2017) explored the dark-side of buyer-seller relationships, in which different partners within supply chain channels could struggle to manage the interplay between cooperation and competition. Following its revised definition, coopetition has been extended to apply to vertical forms of inter-firm cooperation (Bengtsson and Kock, 2014). That is, while this current paper focuses on traditional (horizontal) coopetition, vertical coopetition involves two or more supply chain partners simultaneously cooperating and competing (Yami and Nemeh, 2014; Leite et al., 2018). For example, Velu (2019) illustrated that Samsung supplies some of the components for the Apple iPhone, meaning that these two firms are rival entities, but also, have some important forms of collaboration. Grandinetti (2017) conceptualised that vertical coopetition relationships can be damaged by secrets and power imbalances between the firms involved. Again, if the interplay between cooperation and competition is unstable, there can be negative outcomes for 
the businesses engaging in such strategies (Raza-Ullah et al., 2014; Mattsson and Tidstrom, 2015). The conceptual framework follows in the next section.

\section{Conceptual framework and hypothesis development}

\section{Conceptual framework}

Under resource-based theory and the relational view (Barney, 1991; Hunt and Morgan, 1995; Dyer and Singh, 1998; Barney et al., 2001; Coviello and Brodie, 2001; Lavie, 2006; O'Cass et al., 2015; Crick, 2018a; Dyer et al., 2018), the study's conceptual framework (Figure 1) examined the non-linear (quadratic) links between coopetition and three assessments of company performance (Luo et al., 2007; Ang, 2008; Crick, 2019), namely, customer satisfaction performance $(\mathrm{H} 1)$, market performance $(\mathrm{H} 2)$, and financial performance $(\mathrm{H} 3)$ (measures guided by Hooley et al., 2005; Vorhies and Morgan, 2005; Morgan et al., 2009). Furthermore, the outcome variables were controlled by firm size, firm age, degree of internationalisation, and regional competitiveness, as additional factors that could explain their variances (Westhead et al., 2001; Low, 2007; Cadogan et al., 2009; Felzensztein and Deans, 2013; Lai and Woodside, 2015; Crick and Crick, 2016b; Geldes et al., 2017; Felzensztein et al., 2018; Crick et al., 2019b). For clarity, the non-linear (quadratic) relationships between coopetition and the three company performance outcomes were used to delve deeper into the dark-side of such activities (building upon Tidstrom, 2009; Fang et al., 2011; Abosag et al., 2016; Chowdhury et al., 2016; Crick et al., 2019a; Raza-Ullah, 2019).

$$
\text { [Insert Figure } 1 \text { about here] }
$$

\section{Research hypotheses}

Market orientation surrounds how businesses attempt to implement the marketing concept via satisfying their customers' wants and needs to a superior extent over rivals 
(Kohli and Jaworski, 1990; Narver and Slater, 1990). Yet, some organisations lack the resources and capabilities to deliver performance-driving market-oriented behaviours (Pelham and Wilson, 1995). By collaborating with rival organisations, firms are provided with new ways to satisfy their customers' wants and needs, in terms accessing new market intelligence (Rindfleisch and Moorman, 2003). Yet, "cooperation with competitors needs to be carefully considered and judiciously executed because an over-reliance on highly-intensive competitor alliances may be just as harmful as under-using such alliances. Excessive cooperation may lead to freeriding and opportunistic exploitation, a potential loss of proprietary technological and marketing capabilities, and a possible dulling of a firm's incentives to stay customerfocused" (Luo et al., 2007, p. 81). Businesses must be careful to engage in an "optimallevel" of coopetition to mitigate the risk of yielding such negative outcomes (Crick, 2019). Otherwise, coopetition could have a diminishing-returns effect with customer satisfaction performance.

Specifically, with "too little" coopetition, firms might be forced to compete under an individualistic business model, with an insufficient volume of resources and capabilities to create value for their customers (Ritala et al., 2014; Velu, 2016). Following the resource-based view, as companies acquire new resources and capabilities, their performance is likely to be increased (Barney, 1991; Hunt and Morgan, 1995; Barney et al., 2001; O'Cass et al., 2015). While engaging in coopetition strategies might provide businesses with new resources, capabilities, and opportunities, if they engage in excessive degrees of such activities, there can be a range of negative outcomes (following Luo et al., 2007). Often, when trying to implement the marketing concept, companies maximise their customer value provision through some form of a unique selling point to create a competitive advantage (Kumar et al., 2011). However, if firms 
excessively collaborate with their competitors, they might lose the intellectual property that yields competitive advantages (Ritala and Hurmelinna-Laukkanen, 2013). Hence, linking with the relational view, "too much" coopetition could limit an organisation's ability to create value for customers, with diluted points-of-differentiation, among other negative outcomes (Dyer and Singh, 1998; Lavie, 2006; Dyer et al., 2018; Crick, 2019). Therefore, it is expected that:

H1. A non-linear (quadratic) relationship exists between coopetition and customer satisfaction performance.

Coopetition facilitates access to new resources, capabilities, and opportunities that companies would not normally acquire under individualistic business models (Ritala et al., 2014; Velu, 2019). Through coopetition, organisations can increase the chances of securing competitive advantages by combining rivals' assets with their own resources and capabilities (Crick, 2015). This is especially important for smaller entities that possess limited resources and capabilities and might struggle to outperform their competitors under individualistic business models (Crick, 2018a). However, even if the firms involved are highly-collaborative, they are still their rivals (Park et al., 2014; Arslan, 2018; Cui et al., 2018). According to Tidstrom (2014), if firms engage in coopetition, they risk yielding tensions with their competitors, such as conflict and power imbalances. Thus, with "too little" coopetition, firms might struggle to improve their market performance, with an insufficient resource base (Combs and Ketchen Jr., 1999; Ritala et al., 2014); with "too much" coopetition, there could be increasing forms of inter-firm tensions, where competitive and cooperative forces cannot be differentiated (Tidstrom, 2009; Mattsson and Tidstrom, 2015; Gnyawali et al., 2016; Tidstrom et al., 2018). 
Under resource-based theory, by collaborating with competitors, organisations have access to new resources and capabilities that allow them to enter new markets, satisfy customers' wants and needs, and in turn, yield more sales revenue (Rusko, 2011; Ritala, 2012; Bouncken and Kraus, 2013; Bouncken et al., 2016; Hannah and Eisenhardt, 2018). However, resource-based theory only explains why higher-levels of coopetition can improve company performance (Combs and Ketchen Jr., 1999; Bouncken et al., 2015). In other words, resource-based theory does not account for the potential diminishing-returns effect with company performance. By linking resource-based theory with the relational view, business-to-business marketing scholars can better-understand that if firms engage in excessive degrees of coopetition, they might witness high-quality inter-firm relations becoming negative, in terms of de-stabilising the paradoxical forces of cooperativeness and competitiveness (Raza-Ullah et al., 2014; Gnyawali et al., 2016; Raza-Ullah, 2019). If firms cannot sufficiently manage the interplay between cooperation and competition, they reduce their ability to yield a competitive advantage, since such performance-driving information might have been stolen by rivals (Luo et al., 2007; Chowdhury et al., 2016; Crick, 2019). Consequently, it follows that:

H2. A non-linear (quadratic) relationship exists between coopetition and market performance.

Coopetition activities can assist organisations in saving costs and obtaining higherlevels of sales revenues than if they competed on the basis of their own resources and capabilities (Bengtsson and Kock, 1999; Dahl, 2014; Sanou et al., 2016). Indeed, coopetition can help companies to operate more efficiently within their competitive business environments, with new information that would not exist under individualistic business models (Ritala et al., 2014; Velu, 2016). While coopetition might improve 
financial performance (Ritala, 2012; Bouncken et al., 2016), such outcomes could have a diminishing-returns effect (Luo et al., 2007; Ang, 2008; Crick, 2019). Specifically, if firms do not engage in coopetition, it is apparent that some would struggle to survive within their markets, due to lacking a sufficient volume of resources and capabilities (Granata et al., 2018). If firms excessively collaborate with their competitors, they could lose unique selling points (and intellectual property) - harming their financial performance (Ritala and Hurmelinna-Laukkanen, 2013). With lost unique selling points, firms have less scope to generate sales revenues from their customers and are placed with a competitive disadvantage (Hunt, 1997).

The resource-based view is effective in explaining how coopetition strategies help organisations to improve their performance (Crick, 2018a). By collaborating with their rivals, firms can overcome some of the risks of operating an individualistic business model (Ritala et al., 2014; Velu, 2019). Yet, the resource-based view can overlook how "too much" coopetition can yield decreasing-levels of financial performance (as per Luo et al., 2007). By linking resource-based theory with the relational view, business-to-business marketing scholars can appreciate that excessive degrees of coopetition can yield poor-quality relationships between rival firms (tensions) (Dyer et al., 2018; Crick, 2019). While there can be a range of positive financial consequences for organisations engaging in coopetition strategies (Ritala, 2012; Bouncken and Kraus, 2013; Sanou et al., 2016), it is more likely that if firms continue to collaborate with their rivals, they risk lessening their financial success, due to the odds of diluting their competitive advantages and losing intellectual property (Ang, 2008; Ritala and Hurmelinna-Laukkanen, 2013). If companies are required to invest into failed or failing coopetition partnerships (Luo, 2007; Estrada and Dong, 2019), these extra costs could harm their financial performance. Accordingly, it is anticipated that: 
H3. A non-linear (quadratic) relationship exists between coopetition and financial performance.

\section{Control variables}

The outcome variables (customer satisfaction performance, market performance, and financial performance) were controlled by the following factors. First, firm size was used as a control variable because under resource-based theory and the relational view, larger organisations have more scope to out-perform smaller firms, with fewer resources and capabilities (Barney, 1991; Hunt and Morgan, 1995; Dyer and Singh, 1998; Barney et al., 2001; Crick and Crick, 2018). Second, firm age featured as a control variable, as resource-based theory and the relational view have considered other ways that businesses can improve their performance than via their size and scale (Lavie, 2006; Morgan et al., 2009; Crick and Crick, 2014). For instance, Westhead et al. (2001) highlighted that some entities can compete through their age and market experience to out-perform their rivals. Third, internationalisation can yield greater sales that would not exist in a home market (following Low, 2007; Cadogan et al., 2009; Javalgi et al., 2011; Crick and Crick, 2016c; Crick et al., 2019b). Thus, the outcome variables were controlled by degree of internationalisation. Fourth, linking with resource-based theory and the relational view, if firms compete in regions where there are a large number of rivals, there might be ample opportunities for coopetition to occur (Felzensztein et al., 2012; Felzensztein and Deans, 2013; Crick, 2015; Geldes et al., 2017). That is, with more rivals located within a close geographic proximity, companies can access coopetition partners with complementary business models (Crick, 2019). Hence, regional competitiveness was used as a control variable. The adopted methodology follows in the next section. 


\section{Methodology}

\section{Empirical context}

The population of interest used within this study was the New Zealand wine industry. This empirical context was chosen because it hosts high-degrees of cooperativeness and competitiveness (Felzensztein et al., 2014). As coopetition is the interplay between cooperation and competition (Bengtsson and Kock, 1999; Bouncken et al., 2015; Gnyawali et al., 2016; Chou and Zolkiewski, 2018), scholars should select an empirical setting that manages cooperative and competitive behaviours to bestunderstand the construct (Crick, 2018b). These forces have been found to exist within the business-to-business marketing strategies of New Zealand vineyards and wineries (Felzensztein et al., 2014). Moreover, the owner-managers of such entities have been reported to have varied performance objectives, with some being lifestyle-oriented and others being growth-oriented (Crick and Crick, 2015). This was important, since in this current paper, company performance was considered in three capacities, meaning that it was ideal to utilise a sector that assesses such outcomes in different ways. Additionally, vineyards and wineries have varied degrees of internationalisation (Granata et al., 2018), meaning that this sector could facilitate the evaluation of such a control path. Hence, the New Zealand wine industry was a suitable empirical context to test the research hypotheses and control paths.

\section{Key informants}

The key informants were the managers of the sampled New Zealand vineyards and wineries. That is, coopetition has typically been explored as a managerial activity (Combs and Ketchen Jr., 1999; Tidstrom, 2009; Rusko, 2011; Ritala, 2012; Velu, 2016; Tidstrom et al., 2018). The reason being is that managers are usually the 
individuals that have the authority and decision-making capabilities to collaborate with their competitors (Luo, 2005; Park et al., 2014; Bouncken et al., 2016; Crick and Crick, 2016a; Felzensztein et al., 2018). In addition, the constructs within the conceptual framework were deemed to be best-answered by individuals with a managerial position. For instance, when answering questions on customer satisfaction performance, market performance, and financial performance, such measurement scales were better-suited to managers, rather than non-managers (who might not have known the answers to the questions) (Kohli and Jaworski, 1990; Narver and Slater, 1990; Phillips, 1994; Hooley et al., 2005). While some authors have taken a stakeholder-wide view to studying coopetition (Akpinar and Vincze, 2016; Bengtsson et al., 2016), managers were chosen as the key informants during this study.

Mono-level analysis in the research design

According to Bengtsson et al. (2016), to extend the coopetition literature, business-tobusiness marketing scholars should explore how numerous stakeholders affect the interplay between cooperation and competition. They recommended using novel empirical contexts and research methods that can investigate the multiple-levels of coopetition activities. While Bengtsson et al.'s (2016) paper was a helpful guide to undertaking empirical research to strengthen the existing theory pertaining to the coopetition construct, only certain issues were followed in this current paper. It was of interest to respond to several calls for research to explore the complexities of the relationship between coopetition and company performance (Shu et al., 2017; Hoffmann et al., 2018). Consequently, a mono-level research design was implemented that was best-suited to achieving this research objective. Plus, resource-based theory and the relational view are normally studied from a managerial perspective (Barney, 1991; Dyer and Singh, 1998; Barney et al., 2001; Lavie, 2006; Dyer et al., 2018). 
Therefore, managers were appropriate key informants; sampling various individuals would be better-aligned to stakeholder theory (Akpinar and Vincze, 2016). Nevertheless, such a methodology could be undertaken in future research.

\section{Sampling frame}

This study utilised a public database (via electronic sources) listing the 1,348 alcohol producers in New Zealand. After refining this database to only contain vineyards and wineries, 726 organisations remained, for which this information was used as the sampling frame. Subsequently, this electronic database was compared against the official New Zealand Winegrowers Association's (2019) website to ensure that these vineyards and wineries were still trading (revealing no concerns). To undertake a pilot

study (as explained later), 80 companies were randomly selected, meaning that 646 businesses were used as the population for the core study. To test the research hypotheses and control paths, an electronic survey (using Qualtrics) was developed. Electronic surveys can yield decent response rates, raw data can be automatically transferred to statistical data analysis software (e.g., SPSS 23), and they are more interactive for respondents than mail surveys (Deutskens et al., 2006; Hulland et al., 2018). To generate valid and reliable results, the constructs within the conceptual framework were operationalised and included in the electronic survey.

\section{Data collection techniques}

Once the electronic survey was designed, it was pre-tested with a sample of academics $(n=10)$ who could comment on any theoretical issues that should be explored (see Reynolds and Diamantopoulos, 1998). Then, the electronic survey was pre-tested with a sample of practitioners $(n=15)$, namely, the managers of New Zealand vineyards and wineries, focusing on any practical issues (see Harris and 
Ogbonna, 2001). Afterwards, a pilot study was undertaken, in which 20 usable responses were collected from a random sub-sample of 80 organisations. The scale reliabilities and descriptive statistics were analysed (following Hunt et al., 1982). As there were no concerns with the pilot study data, the core study was implemented. From the remaining 646 firms, 81 usable responses were collected. Since the measures used in the pilot study were identical to those used in the core study, these two datasets were merged to yield a larger sample size $^{2}$ (following Morgan and Hunt, 1994). Thus, the final sample was 101 responses from a population of 726 companies (including the pilot firms) - a $13.91 \%$ response rate.

\section{Operationalisations of the constructs}

The constructs within the conceptual framework were operationalised as follows (see Appendix 1 for a full-list of the multi-item measures). First, coopetition was measured on a seven-point Likert scale, with four items, ranging from: 1 = very strongly disagree to 7 = very strongly agree (adapted from Bouncken and Kraus, 2013; Bouncken et al., 2018). Second, customer satisfaction performance was captured on a seven-point Likert scale, with four items, ranging from: $1=$ much worse than competitors to $7=$ much better than competitors (adapted from Vorhies and Morgan, 2005). Third, market performance was operationalised on a seven-point Likert scale, with four items, ranging from: $1=$ much worse than competitors to $7=$ much better than competitors (adapted from Hooley et al., 2005). Fourth, financial performance was measured on a

\footnotetext{
2 The data were assessed for early, vis-à-vis, late response bias by conducting $t$-tests for each construct, revealing non-significant significant differences (Armstrong and Overton, 1977). In addition, the final sample size $(n=101)$ was deemed to be satisfactory, considering the limited time and prior commitments of the respondents, as well as other sample sizes in the business-to-business marketing literature (e.g., Moorman, 1995; Westerlund and Rajala, 2010; Keinanen and Kuivalainen, 2015; Singh et al., 2017).
} 
seven-point Likert scale, with five items, ranging from: 1 = much worse than competitors to $7=$ much better than competitors (adapted from Morgan et al., 2009). Fifth, firm size was measured by summating the number of full-time and part-time employees and transforming the value by a natural logarithm to reduce its variance (see Peng and Luo, 2000).

Sixth, firm age was operationalised as the number of years since the respondents' businesses had been established (as per Westhead et al., 2001). This score was transformed by a natural logarithm to reduce its variance. Seventh, degree of internationalisation was measured by the firms' export ratios, namely, the percentage of their sales that originated from export markets (see Cadogan et al., 2009). A natural logarithm was used to reduce this construct's variance. Eighth, regional competitiveness was operationalised in multiple stages (a new measure). The respondents were asked for the region that their vineyard and winery is located, in which they selected an option from a list of the main wine regions of New Zealand. Then, via industry data, the number of vineyards and wineries in each region was used to measure the variable (see New Zealand Winegrowers Association, 2019). This value was transformed by a natural logarithm to reduce its variance. Ninth, the survey ended with an informant quality measure that was captured on a seven-point Likert scale, with three items, ranging from: $1=$ very strongly disagree to $7=$ very strongly agree (adapted from Hultman et al., 2009).

Data analysis techniques

The following data analysis techniques were utilised within this investigation. First, the descriptive statistics of the raw data were reviewed using SPSS 23 , with a focus on the standard deviations (SDs) and variances of the measurement scales (Churchill Jr., 
1979). Second, via SPSS 23, the scale reliabilities of the initial measures were recorded through Cronbach's alpha coefficient $(\alpha)$, as well as the scale reliabilities if individual items were deleted (Peterson, 1994). Third, through SPSS 23, an exploratory factor analysis was conducted using a principal components analysis extraction and a varimax rotation (Steenkamp et al., 1994). The Kaiser-Meyer-Olkin (KMO) test of sampling adequacy was employed, alongside Bartlett's test of sphericity (Melewar et al., 2017). During the exploratory factor analysis, to extract the best measures possible (and avoiding cross-factor loadings), factor loadings that were less than 0.60 were suppressed (Peterson, 2000). The total variance explained (as a percentage) of the exploratory factor analysis model was recorded (Jayawardhena, 2004). Due to the acceptable results, at this stage of the data analysis, no items were deleted.

Fourth, via LISREL 9.30, a confirmatory factor analysis (measurement model) was used (Bottger et al., 2017). Poor items were deleted, based on having low factor loadings, high error variances, non-significant $t$-values, and issues associated with the modification indices (Steenkamp and Van Trijp, 1991). The error variances for the single-item scales (firm size, firm age, degree of internationalisation, and regional competitiveness) were manually-calculated through subtracting the assumed scale reliability $(0.60)$ from $1.00(0.40)$ and multiplying this value by the item's variance (Souchon et al., 2016). The model fit indices in the confirmatory factor analysis were the chi-square test statistic $\left(\mathrm{X}^{2}\right)$, as well as its degrees of freedom $(d f)$ and significance (Sig.), root mean square error of approximation (RMSEA), comparative fit index (CFI), incremental fit index (IFI), non-normed fit index (NNFI), goodness of fit index (GFI), and standardised root mean square residual (SRMR) (Gerbing and Anderson, 1988; 
Rindfleisch et al., 2008). Fifth, once the final measures had been established ${ }^{3}$, the research hypotheses and control paths were tested through hierarchical regression (Olson et al., 2005; Morgan et al., 2009).

During the hierarchical regression analysis, the non-linear (quadratic) coopetition construct was transformed and tested through residual-centering to alleviate multicollinearity (Cadogan et al., 2009). Residual-centering involved squaring the coopetition construct. Then, the squared value was regressed, with the coopetition construct being used as the independent variable. The unstandardised residuals were saved and were used to test the three research hypotheses. Moreover, during each stage of the hierarchical regression analysis, the $\Delta R^{2}$ (relative to the $\Delta F$ ) was recorded (Morgan et al., 2009). When the non-linear (quadratic) path was added to each model, the change statistics were significant - providing additional support for the testing of the research hypotheses and control paths. Please note that mean-centering can also test non-linear (quadratic) paths, but there is a high-risk of multi-collinearity errors (Echambadi and Hess, 2007). Therefore, residual-centering was a robust procedure in the model-testing stage. In addition, the final stage of the regression analysis was used to test the research hypotheses and control paths, since all independent variables were nested within the model (as per Cadogan et al., 2012).

\section{Reliability and validity}

Reliability was assessed through the Cronbach alpha coefficients $(\alpha)$ of the measures before and after the scale purification stage, revealing that all operationalisations

\footnotetext{
3 The following construct abbreviations were used - coopetition (COOP), customer satisfaction performance (CUST), market performance (MARK), financial performance (FINA), firm size (SIZE), firm age (AGE), degree of internationalisation (EXPORTS), regional competitiveness (REGION), and informant quality (INQ).
} 
yielded scores greater than 0.70 (Peterson, 1994). Face validity was assured, as the electronic survey was pre-tested with a sample of knowledgeable academics and practitioners (Reynolds and Diamantopoulos, 1998; Harris and Ogbonna, 2001). Additionally, face validity was checked through an informant quality scale, evaluating the extent to which the respondents were qualified to participate in the investigation (adapted from Hultman et al., 2009). Content validity was considered by utilising established operationalisations that were adapted from the extant literature (Crick and

Crick, 2019). Convergent validity was checked via the multi-item measures having composite reliabilities (CRs) that were greater than 0.60 and average variance extracted values (AVEs) that were in excess of 0.50 (Hair Jr. et al., 2012). Discriminant validity was tested through squaring the phi matrix correlations (accessed via LISREL 9.30) and comparing them against the AVEs for each construct. As the highest phi matrix correlation was less than the lowest AVE, discriminant validity is highly-likely to exist (Fornell and Larcker, 1981).

\section{Common method variance}

Common method variance was initially assessed through designing the electronic survey in an interactive manner that maximised the respondents' engagement and reduced attrition rates (Podsakoff et al., 2003). This included using a mixture of scale types, colour schemes, and clear text (Hulland et al., 2018). More formally, after the final measurement scales had been established, the marker variable technique was used (Lindell and Whitney, 2001). That is, a construct that was conceptually unrelated to any other variable within the conceptual framework (namely, the informant quality scale) was selected. Then, through SPSS 23 , a bivariate correlation matrix was produced, containing all constructs. Following this, a partial correlation matrix was produced, containing the same latent variables as the previous stage, but controlling 
for the marker variable. Afterwards, the differences between these matrices were averaged. As the average difference was very small (less than $r=0.05$ ), it is highlyunlikely that the statistical data were biased by a common method factor (see Musarra et al., 2016). The study's empirical results are presented as follows.

\section{Results}

Characteristics of the final sample

The characteristics of the final sample suggested that an acceptable mixture of organisations had participated in this investigation, in terms of factors, such as their size, age, export ratios, number of export markets, as well as the experience of the respondents (Table 1).

[Insert Table 1 about here]

\section{Initial scale reliabilities}

The initial scale reliabilities (before they were purified) were assessed using Cronbach's alpha coefficient $(\alpha)$. Such preliminary results were satisfactory, namely, coopetition $(\alpha=0.88)$, customer satisfaction performance $(\alpha=0.93)$, market performance $(\alpha=0.91)$, financial performance $(\alpha=0.94)$, and the informant quality scale $(\alpha=0.94)$.

\section{Exploratory factor analysis}

The items for the coopetition, customer satisfaction performance, market performance, and financial performance constructs loaded onto four factors, with no cross-factor loadings (Table 2). The result from the KMO test of sampling adequacy was pleasing (0.87), as was the result from Bartlett's test of sphericity $\left(X^{2}=1,484.60\right.$; 
$d f=136$; Sig. $=0.00)$. In addition, $79.66 \%$ of the overall variance was explained by the exploratory factor analysis model.

\section{[Insert Table 2 about here]}

Confirmatory factor analysis

Once certain problematic items had been deleted from the measurement model, the remaining indicators possessed high factor loadings, relatively low error variances, and significant $t$-values (Table 3 ). Also, the model fit indices were within the minimum benchmarks $\left(X^{2}=100.64 ; d f=95 ; X^{2} / d f=1.06\right.$; Sig. $=0.33 ; \operatorname{RMSEA}=0.02 ; \mathrm{CFI}=$ $0.99 ; \mathrm{IFI}=1.00 ; \mathrm{NNFI}=0.99 ; \mathrm{GFI}=0.90 ; \mathrm{SRMR}=0.04)$. This signified that the data were well-suited to the measurement model.

[Insert Table 3 about here]

Reliability and validity assessments

Once the measures had been purified, the final scale reliabilities exceeded the minimum reliability thresholds (Table 4). Moreover, for the multi-item measurement scales, at least three indicators were retained to operationalise each latent variable. When testing for discriminant validity, the highest squared phi matrix correlation (0.61) was less than the lowest AVE (0.75), signifying that there were no discriminant validity concerns (Table 5).

[Insert Tables 4 and 5 about here]

Common method variance testing

Using the marker variable technique, common method variance was not found to be a problem, with a very small average difference between the bivariate and partial 
correlation matrices $(r=0.00)$. Furthermore, the informant quality scale had an acceptable variance $(0.55)$, allowing it to be utilised as the marker variable.

Hierarchical regression analysis

Before the research hypotheses and control paths were tested, the bivariate correlations between the latent variables were recorded (Table 6). Following this, the hierarchical regression analysis revealed that all three research hypotheses were supported, with mixed support for the control paths. Also, the model fit summaries of the hierarchical regression analysis were indicative of a decent model fit (Table 7). To supplement the regression coefficients and $t$-values, when the non-linear (quadratic) paths were added, the $\Delta \mathrm{R}^{2}$ (relative to the $\Delta F$ ) were significant. The study's discussion follows in the next section.

[Insert Tables 6 and 7 about here]

\section{Discussion}

Prior to this investigation, the business-to-business marketing literature had conceptualised that by engaging in coopetition, organisations are likely to obtain higher-levels of company performance (Bengtsson and Kock, 2000; Ritala, 2012; Bouncken and Kraus, 2013; Bouncken et al., 2015; Akpinar and Vincze, 2016; Crick, 2018a). Such findings were driven by a body of knowledge surrounding coopetition providing firms with new resources, capabilities, and opportunities that would not be available to them under individualistic business models (Rusko, 2011; Dahl, 2014; Ritala et al., 2014; Bouncken et al., 2018; Chou and Zolkiewski, 2018; Velu, 2019). Yet, very few scholars had considered the potential for a non-linear (quadratic) relationship between coopetition and company performance (Luo et al., 2007; Ang, 2008; Crick, 2019). This was surprising, since there has been an emerging strand of 
research pertaining to the dark-side of coopetition, such as the inter-firm tensions that might exist when two or more rival firms share resources and capabilities (Grayson and Ambler, 1999; Tidstrom, 2009; Fang et al., 2011; Raza-Ullah et al., 2014; Abosag et al., 2016; Grandinetti, 2017; Tidstrom et al., 2018).

Consequently, this current study sought to examine the non-linear (quadratic) relationship between coopetition and company performance in greater depth. Specifically, company performance can be assessed in numerous capacities (Ray et al., 2004; Katsikeas et al., 2016), with organisations having varied performance objectives, such as being lifestyle-oriented, vis-à-vis, growth-oriented (Crick and Crick, 2015; Crick et al., 2018). Henceforth, it was of interest to explore the potential nonlinear (quadratic) relationships between coopetition and customer satisfaction performance, market performance, and financial performance (following the work of Hooley et al., 2005; Vorhies and Morgan, 2005; Morgan et al., 2009). Guided by resource-based theory and the relational view (Dyer and Singh, 1998; Coviello and Brodie, 2001; Hunt and Derozier, 2004; Tzokas and Saren, 2004; Lavie, 2006; O'Cass et al., 2015; Dyer et al., 2018; Hannah and Eisenhardt, 2018), such linkages were tested with new and novel evidence about the extent to which coopetition activities affect these types of company performance and some of the dark-sides of coopetition. This included how such strategies can be harmful for these company performance consequences.

In doing so, this article responded to recent calls for research to explore the complexities of the coopetition - company performance relationship (see Shu et al., 2017; Hoffmann et al., 2018). Regarding H1, the relationship between coopetition and customer satisfaction performance was found to be non-linear (quadratic) $(\beta=-0.26$; $t=-2.58$; Sig. $=0.01)$. This finding implies that if companies engage in "too little" 
coopetition, they might struggle to create value for their customers, with an insufficient volume of tangible and intangible assets (Velu, 2016). By engaging in "too much" coopetition, firms risk creating inter-firm tensions with their competitors, potentially being exploited for their resources and capabilities, and losing the ability to be customer-focused (Luo et al., 2007). With "too much" coopetition, firms might have shared vital information with their competitors that dilutes their competitive advantages (Riatala and Hurmelinna-Laukkanen, 2013). This might limit firms from implementing performance-driving market-oriented behaviours to create value for their customers. Concerning $\mathrm{H} 2$, support was found for the non-linear (quadratic) relationship between coopetition and market performance $(\beta=-0.33 ; t=-3.28$; Sig. $=0.00)$, reinforcing studies that have highlighted that by sharing an excessive volume of resources and capabilities with competing entities, potential competitive advantages can be lost through inter-firm tensions, such as conflict and power imbalances between rivals (Park et al., 2014; Tidstrom, 2014; Tidstrom et al., 2018).

If "too little" coopetition occurs, firms might struggle to survive within their markets (Crick, 2018a). Yet, this result provides more evidence that "too much" coopetition might drive companies to share information that damages their competitive advantages (Chowdhury et al., 2016; Crick, 2019). These negative outcomes could be explained through firms not being able to manage the paradoxical forces of cooperativeness and competitiveness (Fang, 2006; Raza-Ullah et al., 2014; Mattsson and Tidstrom, 2015; Gnyawali et al., 2016). In terms of H3, a non-linear (quadratic) relationship existed between coopetition and financial performance $(\beta=-0.26 ; t=-$ 2.61; Sig. = 0.01), indicating that if "too little" coopetition occurs, companies might not receive enough sales revenues and have high operating costs (Sanou et al., 2016). Though, if "too much" coopetition occurs, certain intellectual property can be lost - 
harming financial performance (Ritala and Hurmelinna-Laukkanen, 2013). If businesses have engaged in "too much" coopetition, they might need to make various monetary and non-monetary investments to mitigate the damage from failed or failing coopetition partnerships (Luo, 2007; Estrada and Dong, 2019). Such investments might contribute to the diminishing-returns effect with financial performance.

The results from the three research hypotheses provide evidence that coopetition could be a performance-driving business-to-business marketing strategy (Ritala, 2012; Bouncken and Kraus, 2013; Bouncken et al., 2016; Crick, 2018a), but is only beneficial up to a certain extent, in which non-linear (quadratic) effects are likely to occur (supporting Luo et al., 2007; Ang, 2008; Crick, 2019). Further, these results highlight that coopetition yields some dark-sides, which are attributed to these nonlinear (quadratic) relationships (Figure 2). Hence, the business-to-business marketing literature that has explored some of the negative aspects of coopetition (e.g., inter-firm tensions) have translated into this current paper, whereby, "too little" and "too much" coopetition should be avoided to mitigate some of these dark-sides (Park et al., 2014; Mattsson and Tidstrom, 2015; Gnyawali et al., 2016; Crick et al., 2019a). If organisations cannot manage the interplay between cooperation and competition, they might experience a range of negative performance consequences (Raza-Ullah et al., 2014; Raza-Ullah, 2019). The results from this current study help to specify what types of company performance outcomes are negatively affected by "too little" or "too much" coopetition. A critical issue is that businesses should engage in an "optimal-level" of coopetition to avoid these dark-sides (Crick, 2019).

[Insert Figure 2 about here] 
Additionally, this paper has supplemented the earlier work related to the dark-sides of business-to-consumer and business-to-business marketing relationships. That is, the extant literature has explored how organisations can yield negative relationships with customers (value co-creation manifesting into value co-destruction) (Patterson and Baron, 2010; Caru and Cova, 2015; Heidenreich et al., 2015; Chowdhury et al., 2016; Zhang et al., 2018; Cabiddu et al., 2019), as well as failed relationships across interfirm strategies (Grayson and Ambler, 1999; Abosag et al., 2016; Grandinetti, 2017; Peters et al., 2018; Crick et al., 2019a). By investigating the non-linear (quadratic) links between coopetition and customer satisfaction performance, market performance, and financial performance, new evidence has emerged on the outcomes that could be harmed by firms engaging in "too little" or "too much" of such strategies. These results emphasise the importance of having high-quality relationships, especially with rival entities (Dyer and Singh, 1998; Dyer et al., 2018). By combining resource-based theory with the relational view, this article highlights the benefits and drawbacks of coopetition through these complementary viewpoints (Lavie, 2006; Crick, 2019).

The resource-based view highlighted that through coopetition strategies, organisations can overcome some of the risks associated with an individualistic business model, in terms of accessing new resources and capabilities (Combs and Ketchen Jr., 1999; Ritala, 2012; Bouncken and Kraus, 2013; Ritala et al., 2014; Crick, 2018a; Velu, 2019). By using conceptualisations from the relational view, this investigation could evaluate the dark-side of coopetition through having a stronger understanding of the importance of managing high-quality inter-firm relationships (Coviello and Brodie, 2001; Dyer et al., 2018) and avoiding de-stabilising the paradoxical forces of cooperativeness and competitiveness (Raza-Ullah et al., 2014; Mattsson and Tidstrom, 2015; Gnyawali et al., 2016). As a closing point, most of the 
control paths lacked support, with the only exception being the link between degree of internationalisation and financial performance $(\beta=0.20 ; t=1.94$; Sig. $=0.06)$ (supplementing Low, 2007; Cadogan et al., 2009; Javalgi et al., 2011; Crick et al., $2019 b)$. Thus, it is inferred that the core variables were explanatory factors of the different assessments of company performance. This study is concluded as follows.

\section{Conclusions}

\section{Summary}

The objective of this investigation was to examine the non-linear (quadratic) relationships between coopetition and customer satisfaction performance, market performance, and financial performance. Using conceptualisations from resourcebased theory and the relational view, a conceptual framework, with three research hypotheses and various control variables, was developed and tested with survey data from the New Zealand wine industry. The results yielded the following three conclusions that strengthen the business-to-business marketing literature. First, it is concluded that coopetition has non-linear (quadratic) links with customer satisfaction performance, market performance, and financial performance. Second, it is also concluded that the coopetition construct possesses certain dark-sides, in which "too little" and "too much" coopetition can be harmful for company performance. Third, it is lastly concluded that coopetition can be a beneficial strategy for organisations (compared with an individualistic business model), but entities should be cautious about the extent to which they collaborate with their competitors.

\section{Practitioner implications}

In addition to its theoretical contribution, this paper has some implications for practitioners. First, organisations should embrace the benefits of collaborating with 
their competitors, such as acquiring new resources, capabilities, and opportunities that they would not have access to under individualistic business models. Second, after firms have obtained these benefits from coopetition, they should be careful not to engage in excessive forms of such activities. The reason being is that "too little" and "too much" coopetition can reduce various types of company performance (customer satisfaction performance, market performance, and financial performance). Firms are recommended to establish the boundaries of their coopetition partnerships. That is, it is important for companies (via written or unwritten agreements) to acknowledge how they will simultaneously cooperate and compete in advance of coopetition strategies being implemented. This could be a practical tool to reduce any harmful performance consequences (i.e., dark-sides) of coopetition activities.

As an illustration, if businesses are operating in agricultural markets (like the New Zealand vineyards and wineries sampled in this current article), they might collaborate via sharing knowledge and equipment, but have upfront agreements (formal or informal) that they are still competing for the same customers. This simple acknowledgement could create transparency between industry rivals. The same principles could apply in other industries that host firms prepared to engage in coopetition. However, regardless of the empirical context, organisations must carefully collaborate with their competitors and understand the boundaries between cooperation and competition. Third, to mitigate some of the dark-sides of coopetition, businesses should engage in resource and capability-sharing activities to the extent where their performance is improved, but must maintain an individual presence in their markets that reduces any dependency on their competitors' assets. If firms can manage coopetition, alongside an individualistic business model, their performance is likely to be unharmed by the negative aspects of coopetition. 


\section{Limitations and avenues for future research}

While this investigation has contributed to the business-to-business marketing literature, there are certain limitations that can be addressed in future research. First, this paper utilised data from a sample of 101 New Zealand vineyards and wineries. Although this sample size accounted for a respectable response rate (13.91\%), it was relatively small. As such, in future research, scholars should attempt to replicate this study with larger sample sizes. Second, following on, the survey data originated from one industry. Despite the chosen empirical context hosting high-degrees of cooperativeness and competitiveness (needed to explore coopetition), it was a very specific setting. Should academics build upon this paper, they are recommended to sample multiple industries (e.g., sporting organisations, agricultural markets, automotive manufacturers, and high-tech firms) to increase the chances of obtaining generalisable results. Third, except for regional competitiveness, the study used single-source survey data. In future research, it would be interesting to use a mixture of primary and secondary data, such as measuring financial performance through archival sources. This could also include sampling various respondents to obtain a stakeholder-wide view of coopetition. It is fully-appreciated that this would be a methodological challenge, but is a helpful tool to understand the multiple-levels of coopetition. In closing, these limitations do not pose major concerns, but instead, present ample scope for future research. 


\section{References}

Abosag, I., Yen, D.A. and Barnes, B.R. (2016), "What is dark about the dark-side of business relationships?”, Industrial Marketing Management, Vol. 55 No. 1, pp. 59.

Akpinar, M. and Vincze, Z. (2016), "The dynamics of coopetition: a stakeholder view of the German automotive industry", Industrial Marketing Management, Vol. 57 No. 1, pp. 53-63.

Andersson, P. and Nyberg, A. (1998), "Marketing cooperation in automotive strategic alliances", Journal of Business-to-Business Marketing, Vol. 4 No. 3, pp. 43-74.

Ang, S.H. (2008), "Competitive intensity and collaboration: impact on firm growth across technological environments", Strategic Management Journal, Vol. 29 No. 10, pp. 1057-1075.

Armstrong, J.S. and Overton, T.S. (1977), "Estimating nonresponse bias in mail surveys", Journal of Marketing Research, Vol. 14 No. 3, pp. 396-402.

Arslan, B. (2018), "The interplay of competitive and cooperative behavior and differential benefits in alliances", Strategic Management Journal, Vol. 39 No. 2, pp. 3222-3246.

Barney, J.B. (1991), "Firm resources and sustained competitive advantage", Journal of Management, Vol. 17 No. 1, pp. 99-120.

Barney, J.B., Wright, M. and Ketchen Jr. (2001), "The resource-based view of the firm: ten years after 1991”, Journal of Management, Vol. 27 No. 6, pp. 625-641.

Bengtsson, M. and Kock, S. (1999), "Cooperation and competition in relationships between competitors in business networks", Journal of Business \& Industrial Marketing, Vol. 14 No. 3, pp. 178-194.

Bengtsson, M. and Kock, S. (2000), "Coopetition in business networks: to cooperate and compete simultaneously", Industrial Marketing Management, Vol. 29 No. 5, pp. 411-426.

Bengtsson, M. and Kock, S. (2014), "Coopetition - quo vadis? Past accomplishments and future challenges", Industrial Marketing Management, Vol. 43 No. 2, pp. 180188.

Bengtsson, M. and Raza-Ullah, T. (2016), "A systematic review of research on coopetition: toward a multi-level understanding", Industrial Marketing Management, Vol. 57 No. 1, pp. 23-39.

Bengtsson, M., Kock, S., Lundgren-Henriksson, E-L. and Nasholm, M.H. (2016), "Coopetition research in theory and practice: growing new theoretical, empirical, and methodological domains", Industrial Marketing Management, Vol. 57 No. 1, pp. 4-11.

Bouncken, R.B. and Kraus, S. (2013), "Innovation in knowledge-intensive industries: the double-edged sword of coopetition", Journal of Business Research, Vol. 66 No. 10 , pp. 2060-2070. 
Bouncken, R.B., Clauß, T. and Fredrich, V. (2016), "Product innovation through coopetition in alliances: singular or plural governance?", Industrial Marketing Management, Vol. 53 No. 1, pp. 77-90.

Bouncken, R.B., Fredrich, V., Ritala, P. and Kraus, S. (2018), "Coopetition in new product development alliances: advantages and tensions for incremental and radical innovation", British Journal of Management, Vol. 29 No. 3, pp. 391-410.

Bouncken, R.B., Gast, J., Kraus, S. and Bogers, M. (2015), "Coopetition: a systematic review, synthesis, and future research directions", Review of Managerial Science, Vol. 9 No. 3, pp. 577-601.

Bottger, T., Rudolph, T., Evanschitzky, H. and Pfrang, T. (2017), "Customer inspiration: conceptualization, scale development, and validation", Journal of Marketing, Vol. 81 No. 6, pp. 116-131.

Brandenburger, A.M. and Nalebuff, B.J. (1996), Co-opetition, Doubleday Dell Publishing Group Inc., New York: NY.

Cabiddu, F., Moreno, F. and Sebastiano, L. (2019), "Toxic collaborations: codestroying value in the B2B context", Journal of Service Research, Vol. 22 No. 3, pp. 241-255.

Cadogan, J.W., Kuivalainen, O. and Sundqvist, S. (2009), "Export market-oriented behavior and export performance: quadratic and moderating effects under differing degrees of market dynamism and internationalization", Journal of International Marketing, Vol. 17 No. 4, pp. 71-89.

Cadogan, J.W., Sundqvist, S., Puumalainen, K. and Salminen, R.T. (2012), "Strategic flexibilities and export performance: the moderating roles of export marketoriented behavior and the export environment", European Journal of Marketing, Vol. 46 No. 10, pp. 1418-1452.

Caru, A. and Cova, B. (2015), "Co-creating the collective service experience", Journal of Service Management, Vol. 26 No. 2, pp. 276-294.

Chou, H.H. and Zolkiewski, J. (2018), "Coopetition and value creation and appropriation: the role of interdependencies, tensions and harmony", Industrial Marketing Management, Vol. 70 No. 1, pp. 25-33.

Chowdhury, I.N. Gruber, T. and Zolkiewski, J. (2016), "Every cloud has a silver lining: exploring the dark side of value co-creation in B2B service networks", Industrial Marketing Management, Vol. 55 No. 1, pp. 97-109.

Churchill Jr., G.A. (1979), "A paradigm for developing better measures of marketing constructs", Journal of Marketing Research, Vol. 16 No. 1, pp. 64-73.

Combs, J.G. and Ketchen Jr., D.J. (1999), "Explaining inter-firm cooperation and performance: toward a reconciliation of predictions from the resource-based view and organizational economics", Strategic Management Journal, Vol. 20 No. 9, pp. 867-888.

Cortez, R.M. and Johnston, W.J. (2019), "Marketing role in B2B settings: evidence from advanced, emerging and developing markets", Journal of Business \& Industrial Marketing, Vol. 34 No. 3, pp. 605-617. 
Coviello, N.E. and Brodie, R.J. (2001), "Contemporary marketing practices of consumer and business-to-business firms: how different are they?", Journal of Business \& Industrial Marketing, Vol. 16 No. 5, pp. 382-400.

Crick, D. and Crick, J.M. (2014), "The internationalization strategies of rapidly internationalizing high-tech UK SMEs: planned and unplanned activities", European Business Review, Vol. 26 No. 5, pp. 421-448.

Crick, D. and Crick, J.M. (2015), "Learning and decision-making in marketing planning: a study of New Zealand vineyards", Marketing Intelligence \& Planning, Vol. 33 No. 5, pp. 707-732.

Crick, D. and Crick, J.M. (2016a), "Coopetition at the sports marketing/entrepreneurship interface: a case study of a Taekwondo organisation", Marketing Intelligence \& Planning, Vol. 34 No. 2, pp. 169-187.

Crick, D. and Crick, J.M. (2016b), "The first export order: a marketing innovation revisited", Journal of Strategic Marketing, Vol. 24 No. 2, pp. 77-89.

Crick, D. and Crick, J.M. (2016c), "An appreciative inquiry into the first export order", Qualitative Market Research: An International Journal, Vol. 19 No. 1, pp. 84-100.

Crick, D., Chaudhry, S. and Crick, J.M. (2018), "Risks/rewards and an evolving business model: a case study of a small lifestyle business in the UK tourism sector", Qualitative Market Research: An International Journal, Vol. 21 No. 2, pp. 143-165.

Crick, J.M. (2015), "Bridging the gap between threshold and dynamic capabilities: a qualitative study of the collaboration strategies of New Zealand wineries", Unpublished Master of Business Studies thesis, Massey University, Wellington, New Zealand.

Crick, J.M. (2018a), "The facets, antecedents and consequences of coopetition: an entrepreneurial marketing perspective", Qualitative Market Research: An International Journal, Vol. 21 No. 2, pp. 253-272.

Crick, J.M. (2018b), "Studying coopetition in a wine industry context: directions for future research", International Journal of Wine Business Research, Vol. 30 No. 3 , pp. 366-371.

Crick, J.M. (2019), "Moderators affecting the relationship between coopetition and company performance", Journal of Business \& Industrial Marketing, Vol. 34 No. 2 , pp. 518-531.

Crick, J.M. and Crick, D. (2018), "Angel investors' predictive and control funding criteria: the importance of evolving business models", Journal of Research in Marketing and Entrepreneurship, Vol. 20 No. 1, pp. 34-56.

Crick, J.M. and Crick, D. (2019), "Developing and validating a multi-dimensional measure of coopetition", Journal of Business \& Industrial Marketing, Vol. 34 No. 4, pp. 665-689.

Crick, J.M., Crick, D. and Chaudhry, S. (2019a), "The dark-side of coopetition: it's not what you say, but the way that you do it", Journal of Strategic Marketing (Forthcoming). 
Crick, J.M., Crick, D. and Chaudhry, S. (2019b), "Entrepreneurial marketing decisionmaking in rapidly internationalising and de-internationalising start-up firms", Journal of Business Research (Forthcoming).

Cui, V., Yang, H. and Vertinsky, I. (2018), "Attacking your partners: strategic alliances and competition between partners in product-markets", Strategic Management Journal, Vol. 39 No. 12, pp. 3116-3139.

Czakon, W. and Czernek, K. (2016), "The role of trust-building mechanisms in entering into network coopetition: the case of tourism networks in Poland", Industrial Marketing Management, Vol. 57 No. 1, pp. 64-74.

Dahl, J. (2014), "Conceptualizing coopetition as a process: an outline of change in cooperative and competitive interactions", Industrial Marketing Management, Vol. 43 No. 2, pp. 272-279.

Dant, R.P. and Gleiberman, A. (2011), "Preventing and combating the onset of darkside symptoms", Journal of Marketing Management, Vol. 27 Nos. 13/14, pp. 14261443.

Daunt, K.L. and Greer, D.A. (2017), "The dark-side of marketing: introduction to the special issue", Journal of Marketing Management, Vol. 33 Nos. 15/16, pp. 12311235.

Daunt, K.L. and Harris, L.C. (2017), "Consumer showrooming: value co-destruction", Journal of Retailing and Consumer Services, Vol. 38 No. 1, pp. 166-176.

Deutskens, E., de Jong, A., de Ruyter, K. and Wetzels, M. (2006), "Comparing the generalizability of online and mail surveys in cross-national service quality research", Marketing Letters, Vol. 17 No. 2, pp. 119-136.

Dyer, J.H. and Singh, H. (1998), "The relational view: cooperative strategy and sources of inter-organizational competitive advantage", Academy of Management Review, Vol. 23 No. 4, pp. 660-679.

Dyer, J.H., Singh, H. and Hesterly, W.S. (2018), "The relational view revisited: a dynamic perspective on value creation and value capture", Strategic Management Journal, Vol. 39 No. 12, pp. 3140-3162.

Echambadi, R. and Hess, J.D. (2007), "Mean-centering does not alleviate collinearity problems in moderated multiple regression models", Marketing Science, Vol. 26 No. 3, pp. 438-445.

Echeverri, P. and Skalen, P. (2011), "Co-creation and co-destruction: a practice-theory based study of interactive value formation", Marketing Theory, Vol. 11 No. 3, pp. 351-373.

Edvardsson, B., Tronvoll, B. and Gruber, T. (2011), "Expanding understanding of service exchange and value co-creation: a social construction approach", Journal of the Academy of Marketing Science, Vol. 39 No. 2, pp. 327-339.

Estrada, I. and Dong, J.Q. (2019), "Learning from experience? Technological investments and the impact of coopetition experience on firm profitability", Long Range Planning (Forthcoming). 
Fang, S-R., Chang, Y-S. and Peng, Y-C. (2011), "Dark-side of relationships: a tensions-based view", Industrial Marketing Management, Vol. 40 No. 5, pp. 774784.

Fang, T. (2006), "Negotiation: the Chinese style", Journal of Business \& Industrial Marketing, Vol. 21 No. 1, pp. 50-60.

Felzensztein, C. and Deans, K.R. (2013), "Marketing practices in wine clusters: insights from Chile", Journal of Business \& Industrial Marketing, Vol. 28 No. 4, pp. 357-367.

Felzensztein, C., Gimmon, E. and Aqueveque, C. (2012), "Clusters or un-clustered industries? Where inter-firm marketing cooperation matters", Journal of Business \& Industrial Marketing, Vol. 27 No. 5, pp. 392-402.

Felzensztein, C., Gimmon, E. and Deans, K.R. (2018), "Coopetition in regional clusters: keep calm and expect unexpected changes", Industrial Marketing Management, Vol. 69 No. 1, pp. 116-124.

Felzensztein, C., Stringer, C., Benson-Rea, M. and Freeman, S. (2014), "International marketing strategies in industrial clusters: insights from the Southern Hemisphere", Journal of Business Research, Vol. 67 No. 5, pp. 837-846.

Fornell, C. and Larcker, D.F. (1981), "Structural equation models with unobservable variables and measurement error: algebra and statistics", Journal of Marketing Research, Vol. 18 No. 3, pp. 382-388.

Geldes, C., Heredia, J., Felzensztein, C. and Mora, M. (2017), "Proximity as determinant of business cooperation for technological and non-technological innovations: a study of an agribusiness cluster", Journal of Business \& Industrial Marketing, Vol. 32 No. 1, pp. 167-178.

Gerbing, D.W. and Anderson, J.C. (1988), "An updated paradigm for scale development incorporating uni-dimensionality and its assessment", Journal of Marketing Research, Vol. 25 No. 2, pp. 186-192.

Gnyawali, D.R. and Charleton, T.R. (2018), "Nuances in the interplay of competition and cooperation: towards a theory of coopetition", Journal of Management, Vol. 44 No. 7 , pp. 2511-2534.

Gnyawali D.R. and Park, B.J.R. (2011), "Coopetition between giants: collaboration with competitors for technological innovation", Research Policy, Vol. 40 No. 5, pp. 650-663.

Gnyawali, D.R., Madhavan, R., He, J. and Bengtsson, M. (2016), "The competitioncooperation paradox in inter-firm relationships: a conceptual framework", Industrial Marketing Management, Vol. 53 No. 1, pp. 7-18.

Grandinetti, R. (2017), "Exploring the dark-side of cooperative buyer-seller relationships", Journal of Business \& Industrial Marketing, Vol. 32 No. 2, pp. 326336.

Granata, J., Lasch, F., Le Roy, F. and Dana, L-P. (2018), "How do micro-firms manage coopetition? A study of the wine sector in France", International Small Business Journal, Vol. 36 No. 3, pp. 331-355. 
Grayson, K. and Ambler, T. (1999), "The dark-side of long-term relationships in marketing services”, Journal of Marketing Research, Vol. 36 No. 1, pp. 132-141.

Gronroos, C. (2009), "Marketing as promise management: regaining customer management for marketing", Journal of Business \& Industrial Marketing, Vol. 24 Nos. 5/6, pp. 351-359.

Hair Jr., J.F., Sarstedt, M., Ringle, C.M. and Mena, J.A. (2012), "An assessment of the use of partial least squares structural equation modelling in marketing research", Journal of the Academy of Marketing Science, Vol. 40 No. 3, pp. 414-433.

Hannah, D.P. and Eisenhardt, K.M. (2018), "How firms navigate cooperation and competition in nascent ecosystems", Strategic Management Journal, Vol. 39 No. 12, pp. 3163-3192.

Harris, L.C. and Ogbonna, E. (2001), "Strategic human resource management, market orientation, and organizational performance", Journal of Business Research, Vol. 51 No. 2, pp. 157-166.

Heidenreich, S., Wittkowski, K., Handrich, M. and Falk, T. (2015), "The dark-side of customer co-creation: exploring the consequences of failed co-created services", Journal of the Academy of Marketing Science, Vol. 43 No. 3, pp. 279-296.

Hoffmann, W., Lavie, D., Reuer, J.J. and Shiplov, A. (2018), "The interplay of competition and cooperation", Strategic Management Journal, Vol. 39 No. 12, pp. 3033-3052.

Hooley, G.J., Greenley, G.E., Cadogan, J.W. and Fahy, J. (2005), "The performance impact of marketing resources", Journal of Business Research, Vol. 58 No. 1, pp. 18-27.

Hulland, J., Baumgartner, H. and Smith, K.M. (2018), "Marketing survey research best practices: evidence and recommendations from a review of JAMS articles", Journal of the Academy of Marketing Science, Vol. 46 No. 1, pp. 92-108.

Hultman, M., Robson, M.J. and Katsikeas, C.S. (2009), "Export product strategy fit and performance: an empirical investigation", Journal of International Marketing, Vol. 17 No. 4, pp. 1-23.

Hunt, S.D. and Derozier, C. (2004), "The normative imperatives of business and marketing strategy: grounding strategy in resource-advantage theory", Journal of Business \& Industrial Marketing, Vol. 19 No. 1, pp. 5-22.

Hunt, S.D. (1997), "Competing through relationships: grounding relationship marketing in resource-advantage theory", Journal of Marketing Management, Vol. 13 No. 5 , pp. 431-445.

Hunt, S.D. and Morgan, R.M. (1995), "The comparative advantage theory of competition", Journal of Marketing, Vol. 59 No. 2, pp. 1-15.

Hunt, S.D., Sparkman Jr. and Wilcox, J.B. (1982), "The pre-test in survey research: issues and preliminary findings", Journal of Marketing Research, Vol. 19 No. 2, pp. 269-273. 
Javalgi, R.R.G., Todd, P. and Granot, E. (2011), "The internationalization of Indian SMEs in B-to-B markets", Journal of Business \& Industrial Marketing, Vol. 26 No. 7, pp. 542-548.

Jayawardhena, C. (2004), "Measurement of service quality in internet banking: the development of an instrument", Journal of Marketing Management, Vol. 20 Nos. $1 / 2$, pp. $185-207$.

Jin, B. and Cho, H.J. (2018), "Examining the role of international entrepreneurial orientation, domestic market competition, and technological and marketing capabilities on SME's export performance", Journal of Business \& Industrial Marketing, Vol. 33 No. 5, pp. 585-598.

Kanter, R.M. (1994), "Collaborative advantage: the art of alliances", Harvard Business Review, Vol. 72 No. 4, pp. 96-108.

Katsikeas, C.S., Morgan, N.A., Leonidou, L.C. and Hult, G.T.M. (2016), "Assessing performance outcomes in marketing", Journal of Marketing, Vol. 80 No. 2, pp. 120.

Keinanen, H. and Kuivalainen, O. (2015), "Antecedents of social media B2B use in industrial marketing context: customers' view", Journal of Business \& Industrial Marketing, Vol. 30 No. 6, pp. 711-722.

Kim, K., Byon, K.K. and Baek, W. (2019), "Customer-to-customer value co-creation and co-destruction in sporting events", The Service Industries Journal (Forthcoming).

Kohli, A.K. and Jaworski, B.J. (1990), "Market orientation: the construct, research propositions, and managerial implications", Journal of Marketing, Vol. 54 No. 2, pp. 1-18.

Komulainen, H. (2014), "The role of learning in value co-creation in new technological B2B services”, Journal of Business \& Industrial Marketing, Vol. 29 No. 3, pp. 238252.

Kumar, V., Jones, E., Venkatesan, R. and Leone, R.P. (2011), "Is market orientation a source of sustainable competitive advantage or simply the cost of competing?", Journal of Marketing, Vol. 75 No. 1, pp. 16-30.

Lai, W-H. and Woodside, A.G. (2015), "Heuristics-in-use in industrial inter-firmcollaborating clusters", Journal of Business \& Industrial Marketing, Vol. 30 Nos. 3/4, pp. 394-404.

Lavie, D. (2006), "The competitive advantage of inter-connected firms: an extension of the resource-based view", Academy of Management Review, Vol. 31 No. 3, pp. 638-658.

Leite, E., Pahlberg, C. and Aberg, S. (2018), "The cooperation-competition interplay in the ICT industry", Journal of Business \& Industrial Marketing, Vol. 33 No. 4, pp. 495-505.

Lindell, M.K. and Whitney, D.J. (2001), "Accounting for common method variance in cross-sectional research designs", Journal of Applied Psychology, Vol. 86 No. 1, pp. 114-121. 
Low, B. (2007), "Huawei Technologies Corporation: from local dominance to global challenge?", Journal of Business \& Industrial Marketing, Vol. 22 No. 2, pp. 138144.

Luo, X., Rindfleisch, A. and Tse, D.K. (2007), "Working with rivals: the impact of competitor alliances on financial performance", Journal of Marketing Research, Vol. 44 No. 1, pp. 73-83.

Luo, X., Slotegraaf, R.J. and Pan, X. (2006), "Cross-functional coopetition: the simultaneous role of cooperation and competition within firms", Journal of Marketing, Vol. 70 No. 2, pp. 67-80.

Luo, Y. (2005), "Toward coopetition within a multinational enterprise: a perspective from foreign subsidiaries”, Journal of World Business, Vol. 40 No. 1, pp. 71-90.

Luo, Y. (2007), "A coopetition perspective of global competition", Journal of World Business, Vol. 42 No. 2, pp. 129-144.

Luu, N., Cadeaux, J. and Ngo, L.V. (2018), "Governance mechanisms and total relationship value: the interaction effect of information-sharing", Journal of Business \& Industrial Marketing, Vol. 33 No. 5, pp. 717-729.

Mattsson, L-G. and Tidstrom, A. (2015), "Applying the principles of yin-yang to market dynamics: on the duality of cooperation and competition", Marketing Theory, 15(3), pp. 347-364.

Melewar, T.C., Foroudi, P., Gupta, S., Kitchen, P.J. and Foroudi, M.M. (2017), "Integrating identity, strategy and communications for trust, loyalty and commitment", European Journal of Marketing, Vol. 51 No. 3, pp. 572-604.

Mick, D.G. (1996), "Are studies of dark-side variables confounded by socially desirable responding? The case of materialism", Journal of Consumer Research, Vol. 23 No. 2, pp. 106-119.

Mohr, J.J. and Sengupta, S. (2002), "Managing the paradox of inter-firm learning: the role of governance mechanisms", Journal of Business \& Industrial Marketing, Vol. 17 No. 4, pp. 282-301.

Moorman, C. (1995), “Organizational market information processes: cultural antecedents and new product outcomes", Journal of Marketing Research, Vol. 32 No. 3, pp. 318-335.

Morgan, N.A., Vorhies, D.W. and Mason, C.H. (2009), "Market orientation, marketing capabilities, and firm performance", Strategic Management Journal, Vol. 30 No. 8, pp. 909-920.

Morgan, R.M. and Hunt, S.D. (1994), "The commitment-trust theory of relationship marketing", Journal of Marketing, Vol. 58 No. 3, pp. 20-38.

Musarra, G., Robson, M.J. and Katsikeas, C.S. (2016), "The influence of desire for control on monitoring decisions and performance outcomes in strategic alliances", Industrial Marketing Management, Vol. 55 No. 1, pp. 10-21.

Narver, J.C. and Slater, S.F. (1990), "The effect of a market orientation on business profitability”, Journal of Marketing, Vol. 54 No. 4, pp. 20-35. 
New Zealand Winegrowers Association. (2019), "Discover our regions", available at: https://www.nzwine.com/en/our-regions/ (accessed 13 January 2019).

O'Cass, A., Ngo, L.V. and Siahtiri, V. (2015), "Marketing resource-capability complementarity and firm performance in B2B firms", Journal of Business \& Industrial Marketing, Vol. 30 No. 2, pp. 194-207.

Olson, E.M., Slater, S.F. and Hult, G.T.M. (2005), "The performance implications of fit among business strategy, marketing organization structure, and strategic behavior", Journal of Marketing, Vol. 69 No. 3, pp. 49-65.

Park, B.J.R., Srivastava, M.K. and Gnyawali, D.R. (2014), "Walking the tight rope of coopetition: impact of competition and cooperation intensities and balance on firm innovation performance", Industrial Marketing Management, Vol. 43 No. 2, pp. 210-221.

Patterson A. and Baron, S. (2010), "Deviant employees and dreadful service encounters: customer tales of discord and distrust", Journal of Services Marketing, Vol. 24 No. 6, pp. 438-445.

Payne, AF., Storbacka, K. and Frow, P. (2008), "Managing the co-creation of value", Journal of the Academy of Marketing Science, Vol. 36 No. 1, pp. 83-96.

Pelham, A.M. and Wilson, D.T. (1995), "A longitudinal study of the impact of market structure, firm structure, strategy, and market orientation culture on dimensions of small-firm performance", Journal of the Academy of Marketing Science, Vol. 24 No. 1, pp. 27-43.

Peng, M.W. and Luo, Y. (2000), "Managerial ties and firm performance in a transition economy: the nature of a micro-macro link", Academy of Management Journal, Vol. 43 No. 3, pp. 486-501.

Peters, L.D., Johnston, W.J., Pressey, A.D. and Kendrick, T. (2010), "Collaboration and collective learning: networks as learning organisations", Journal of Business \& Industrial Marketing, Vol. 25 No. 6, pp. 478-484.

Peters, L.D., Pressey, A.D., Gilchrist, A.J.P. and Johnston, W.J. (2018), "Involving customers in innovation: knowledgeability and agency as process variables", Journal of Business \& Industrial Marketing, Vol. 33 No. 2, pp. 164-173.

Peterson, R.A. (1994), "A meta-analysis of Cronbach's coefficient alpha", Journal of Consumer Research, Vol. 21 No. 2, pp. 381-391.

Peterson, R.A. (2000), "A meta-analysis of variance accounted for and factor loadings in exploratory factor analysis", Marketing Letters, Vol. 11 No. 3, pp. 261-275.

Phillips, L.W. (1981), "Assessing measurement error in key informant reports: a methodological note on organizational analysis in marketing", Journal of Marketing Research, Vol. 18 No. 4, pp. 395-415.

Ple, L. and Caceres, R.C. (2010), "Not always co-creation: introducing interactional co-destruction of value in service-dominant logic", Journal of Services Marketing, Vol. 24 No. 6, pp. 430-437.

Podsakoff, P.M., MacKenzie, S.B., Lee J-Y. and Podsakoff, N.P. (2003), "Common method biases in behavioral research: a critical review of the literature and 
recommended remedies", Journal of Applied Psychology, Vol. 88 No. 5, pp. 879903.

Ranganathan, R., Ghosh, A. and Rosenkopf, L. (2018), "Competition-cooperation interplay during multi-firm technology coordination: the effect of firm heterogeneity on conflict and consensus in a technology standards organization", Strategic Management Journal, Vol. 39 No. 12, pp. 3193-3221.

Ranjan, K.R. and Read, S. (2016), "Value co-creation: concept and measurement", Journal of the Academy of Marketing Science, Vol. 44 No. 3, pp. 290-315.

Ray, G., Barney, J.B. and Muhanna, W.A. (2004), "Capabilities, business processes, and competitive advantage: choosing the dependent variable in empirical tests of the resource-based view", Strategic Management Journal, Vol. 25 No. 1, pp. 2337.

Raza-Ullah, T. (2019), "Experiencing the paradox of coopetition: a moderated mediation framework explaining the paradoxical tension-performance relationship", Long Range Planning (Forthcoming).

Raza-Ullah, T., Bengtsson, M. and Kock, S. (2014), "The coopetition paradox and tension in coopetition at multiple-levels", Industrial Marketing Management, Vol. 43 No. 2, pp. 189-198.

Reynolds N. and Diamantopoulos, A. (1998), "The effect of pre-test method on error detection rates: experimental evidence", European Journal of Marketing, Vol. 32 Nos. 5/6, pp. 480-496.

Rindfleisch, A. and Moorman, C. (2003), "Inter-firm cooperation and customer orientation", Journal of Marketing Research, Vol. 40 No. 4, pp. 421-436.

Rindfleisch, A., Malter, A.J., Ganesan, S. and Moorman, C. (2008), "Cross-sectional versus longitudinal survey research: concepts, findings, and guidelines", Journal of Marketing Research, Vol. 45 No. 3, pp. 261-279.

Ritala, P. (2012), "Coopetition strategy - when is it successful? Empirical evidence on innovation and market performance", British Journal of Management, Vol. 23 No. 3, pp. 307-324.

Ritala, P. and Hurmelinna-Laukkanen, P. (2013), "Incremental and radical innovation in coopetition: the role of absorptive capacity and appropriability", Journal of Product Innovation Management, Vol. 30 No. 1, pp. 154-169.

Ritala, P., Golnam, A. and Wegmann, A. (2014), "Coopetition-based business models: the case of Amazon.com", Industrial Marketing Management, Vol. 43 No. 2, pp. 236-249.

Rusko, R. (2011), "Exploring the concept of coopetition: a typology for the strategic moves of the Finnish forest industry", Industrial Marketing Management, Vol. 40 No. 2, pp. 311-320.

Sanou, F.H., Le Roy, F. and Gnyawali, D.R. (2016), "How does centrality in coopetition networks matter? An empirical investigation in the mobile telephone industry", British Journal of Management, Vol. 27 No. 1, pp. 143-160. 
Shu, C., Jin, J.L. and Zhou, K.Z. (2017), "A contingent view of partner coopetition in international joint ventures", Journal of International Marketing, Vol. 25 No. 3, pp. 42-60.

Singh, J., Shuka, P. and Kalafatis, S.P. (2017), "IT usage for enhancing trade show performance: evidence from the aviation services", Journal of Business \& Industrial Marketing, Vol. 32 No. 3, pp. 398-408.

Sinkovics, R.R., Kuivalainen, O. and Roath, A.S. (2018), "Value co-creation in an outsourcing arrangement between manufacturers and third party logistics providers: resource commitment, innovation and collaboration", Journal of Business \& Industrial Marketing, Vol. 33 No. 4, pp. 563-573.

Skalen, P., Pace, S. and Cova, B. (2015), "Firm-brand community value co-creation as alignment of practices", European Journal of Marketing, Vol. 49 Nos. 3/4, pp. 596-620.

Smith, A.M. (2013), "The value co-destruction process: a customer resource perspective”, European Journal of Marketing, Vol. 47 Nos. 11/12, pp. 1889-1909.

Souchon, A.L., Hughes, P., Farrell, A.M., Nemkova, E. and Oliveira, J.S. (2016), "Spontaneity and international marketing performance", International Marketing Review, Vol. 33 No. 5, pp. 671-690.

Steenkamp, J-B.E.M. and Van Trijp, H.C.M. (1991), "The use of LISREL in validating marketing constructs", International Journal of Research in Marketing, Vol. 8 No. 4, pp. 283-299.

Steenkamp, J-B.E.M., Van Trijp, H.C.M. and Ten Berge, J.M.F. (1994), "Perceptual mapping based on idiosyncratic sets of attributes", Journal of Marketing Research, Vol. 31 No. 1, pp. 15-27.

Strese, S., Meuer, M.W., Flatten, T.C. and Brettel, M. (2016), "Organizational antecedents of cross-functional coopetition: the impact of leadership and organizational structure on cross-functional coopetition", Industrial Marketing Management, Vol. 53 No. 1, pp. 42-55.

Tidstrom, A. (2009), "Causes of conflict in inter-competitor cooperation", Journal of Business \& Industrial Marketing, Vol. 24 No. 7, pp. 506-518.

Tidstrom, A. (2014), "Managing tensions in coopetition", Industrial Marketing Management, Vol. 43 No. 2, pp. 261-271.

Tidstrom, A. and Rajala, A. (2016), "Coopetition strategy as interrelated praxis and practices on multiple-levels", Journal of Business \& Industrial Marketing, Vol. 58 No. 1, pp. 35-44.

Tidstrom, A., Ritala, P. and Lainema, K. (2018), "Interactional and procedural practices in managing coopetitive tensions", Journal of Business \& Industrial Marketing, Vol. 33 No. 7 , pp. $945-957$.

Tzokas, M. and Saren, M. (2004), "Competitive advantage, knowledge and relationship marketing: where, what and how?", Journal of Business \& Industrial Marketing, Vol. 19 No. 2, pp. 124-135. 
Vargo, S.L. and Lusch, R.F. (2004), "Evolving to a new dominant logic for marketing", Journal of Marketing, Vol. 68 No. 1, pp. 1-17.

Velu, C. (2016), "Evolutionary or revolutionary business model innovation through coopetition? The role of dominance in network markets", Industrial Marketing Management, Vol. 53 No. 1, pp. 124-135.

Velu, C. (2019), "Coopetition and business models", in Fernandez, A-S., Chiambaretto, P., Le Roy, F. and Czakon, W. (Eds.), Routledge Companion to Coopetition Strategies, Routledge, New York: NY, pp. 336-346.

Virtanen, H. and Kock, S. (2016), "Tension in coopetition between small- and mediumsized firms", Proceedings of the McGill International Entrepreneurship Conference, Vaasa, Finland.

Vorhies, D.W. and Morgan, N.A. (2005), "Benchmarking marketing capabilities for sustainable competitive advantage", Journal of Marketing, Vol. 69 No. 1, pp. 8094.

Westerlund, M. and Rajala, R. (2010), "Learning and innovation in inter-organizational network collaboration", Journal of Business \& Industrial Marketing, Vol. 25 No. 6 , pp. 435-442.

Westhead, P., Wright, M. and Ucbasaran, D. (2001), "The internationalization of new and small firms: a resource-based view", Journal of Business Venturing, Vol. 16 No. 4, pp. 333-358.

Yami, S. and Nemeh, A. (2014), "Organizing coopetition for innovation: the case of wireless telecommunication sector in Europe", Industrial Marketing Management, Vol. 43 No. 2, pp. 250-260.

Zhang, T., Lu, C., Torres, E. and Chen, P-J. (2018), "Engaging customers in value cocreation or co-destruction online", Journal of Services Marketing, Vol. 32 No. 1, pp. 57-69. 
Figure 1. Conceptual framework

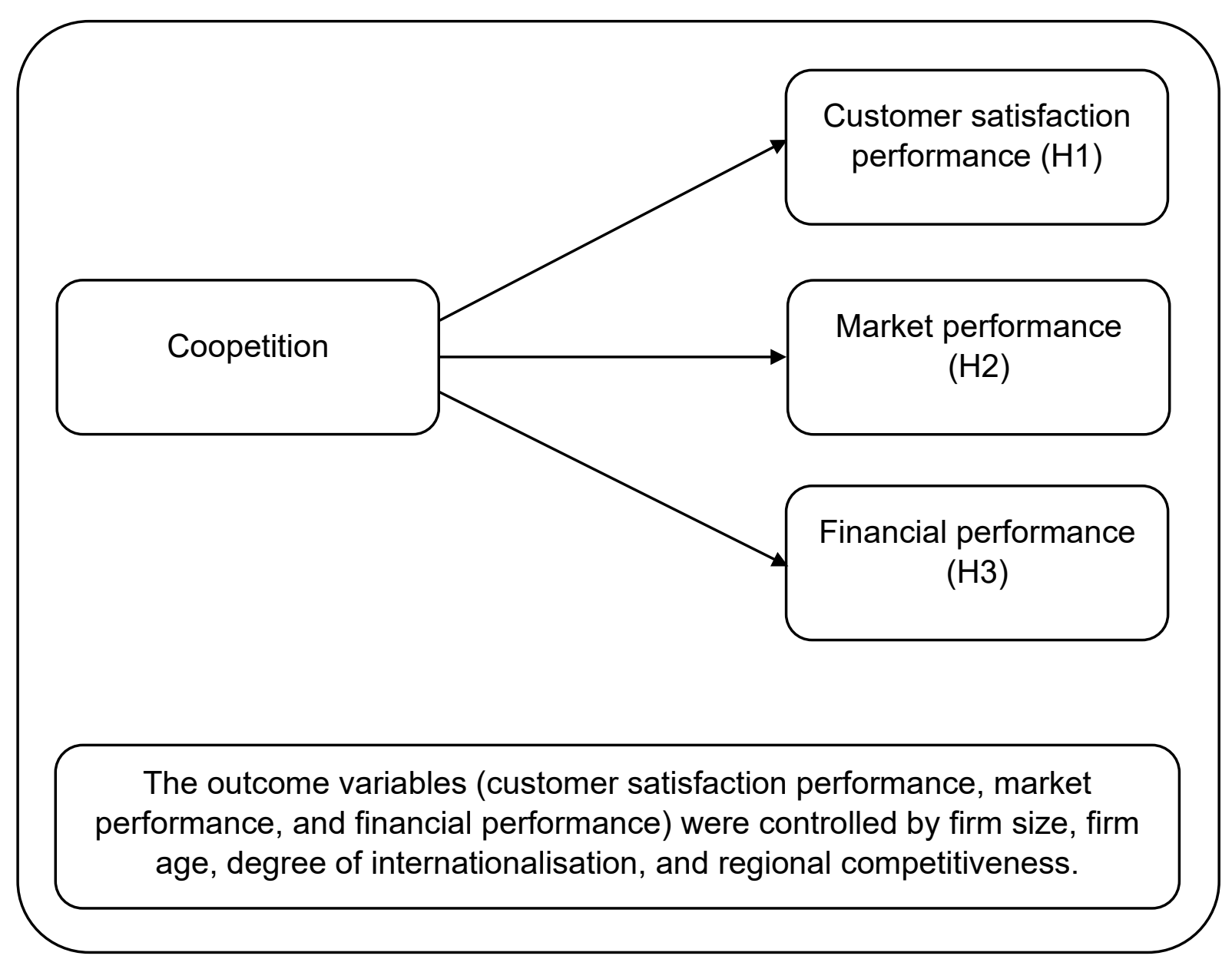


Figure 2. The non-linear (quadratic) relationships between coopetition and three assessments of company performance

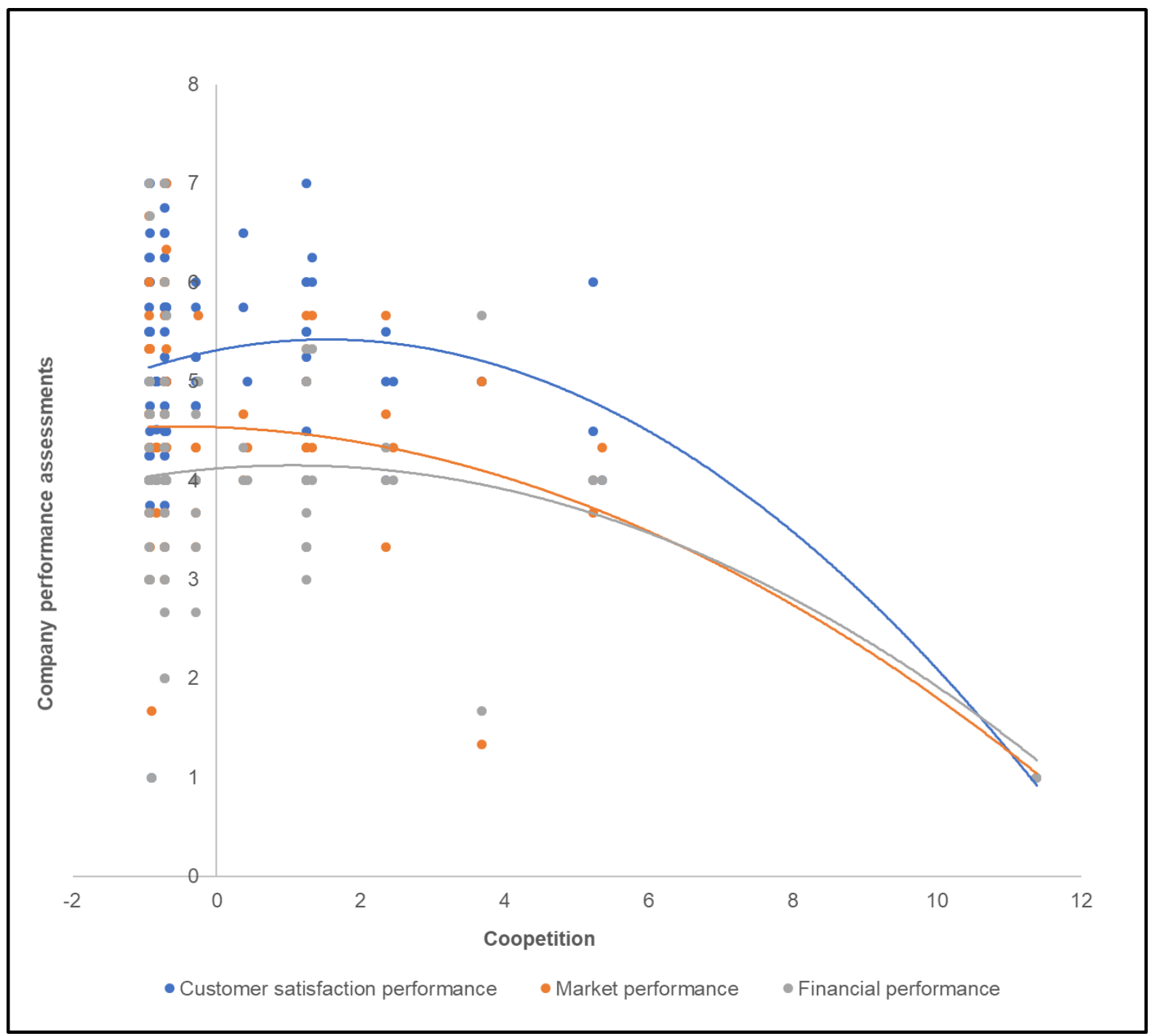


Table 1. Characteristics of the final sample

\begin{tabular}{|l|c|c|c|c|}
\hline Characteristics & Mean & Median & SD & Variance \\
\hline Full-time employees & 13.44 & 5.00 & 27.03 & 730.62 \\
\hline Part-time employees & 12.16 & 5.00 & 23.20 & 538.24 \\
\hline Firm age (years) & 68.95 & 72.00 & 14.42 & 207.82 \\
\hline Industry experience (years) & 18.39 & 18.40 & 10.37 & 107.54 \\
\hline Years in current role & 12.63 & 12.00 & 7.52 & 56.55 \\
\hline Years in current organisation & 14.32 & 12.00 & 9.24 & 85.38 \\
\hline Export ratio & 27.71 & 19.70 & 26.77 & 716.63 \\
\hline Number of export markets & 8.53 & 8.00 & 11.41 & 130.19 \\
\hline Annual sales (\$NZ millions) & 2.34 & 2.20 & 2.52 & 6.35 \\
\hline
\end{tabular}

Table 2. Exploratory factor analysis model

\begin{tabular}{|l|c|c|c|c|}
\hline \multicolumn{5}{|c|}{ Components } \\
\hline Items $^{\text {a }}$ & Factor 1 & Factor 2 & Factor 3 & Factor 4 \\
\hline COOP_1 & 0.77 & & & \\
\hline COOP_2 & 0.87 & & & \\
\hline COOP_3 & 0.89 & & & \\
\hline COOP_4 & 0.89 & & & \\
\hline CUST_1 & & 0.81 & & \\
\hline CUST_2 & & 0.80 & & \\
\hline CUST_3 & & 0.84 & & \\
\hline CUST_4 & & 0.77 & 0.75 & \\
\hline MARK_1 & & & 0.85 & \\
\hline MARK_2 & & & 0.76 & 0.85 \\
\hline MARK_3 & & & 0.65 & 0.78 \\
\hline MARK_4 & & & & 0.83 \\
\hline FINA_1 & & & & \\
\hline FINA_2 & & & & \\
\hline FINA_3 & & & & \\
\hline FINA_4 & & & & \\
\hline FINA_5 & Note: ${ }^{2} T h e$ indicators produced a four-factor solution. & \\
\hline
\end{tabular}


Table 3. Confirmatory factor analysis model

\begin{tabular}{|l|c|c|c|}
\hline Items & Factor loadings & Error variances & $\boldsymbol{t}_{\text {-values }}{ }^{\mathbf{a}}$ \\
\hline COOP_2 & 0.86 & 0.25 & 11.25 \\
\hline COOP_3 & 0.89 & 0.21 & Fixed \\
\hline COOP_4 & 0.83 & 0.30 & 10.69 \\
\hline CUST_1 & 0.89 & 0.20 & 12.79 \\
\hline CUST_2 & 0.85 & 0.28 & 11.56 \\
\hline CUST_3 & 0.88 & 0.23 & Fixed \\
\hline CUST_4 & 0.87 & 0.25 & 12.02 \\
\hline MARK_1 & 0.91 & 0.16 & 13.55 \\
\hline MARK_2 & 0.90 & 0.19 & Fixed \\
\hline MARK_3 & 0.82 & 0.34 & 10.94 \\
\hline FINA_1 & 0.89 & 0.21 & 12.61 \\
\hline FINA_2 & 0.90 & 0.20 & Fixed \\
\hline FINA_3 & 0.87 & 0.25 & 12.11 \\
\hline SIZE & 0.83 & 0.31 & Fixed \\
\hline AGE & 0.86 & 0.26 & Fixed \\
\hline EXPORTS & 0.99 & 0.02 & Fixed \\
\hline REGION & 0.77 & 0.40 & Fixed \\
\hline Note: ${ }^{2}$ The critical $t$-value was $1.65(5 \%$, one-sided). \\
\hline
\end{tabular}

Table 4. Final scale reliabilities

\begin{tabular}{|l|c|c|c|c|}
\hline Variables & Alpha (a) & Items (n) & CR & AVE \\
\hline Coopetition & 0.90 & 3 & 0.90 & 0.75 \\
\hline Customer satisfaction performance & 0.93 & 4 & 0.93 & 0.76 \\
\hline Market performance & 0.91 & 3 & 0.91 & 0.77 \\
\hline Financial performance & 0.91 & 3 & 0.92 & 0.78 \\
\hline
\end{tabular}


Table 5. Discriminant validity test

\begin{tabular}{|c|c|c|c|c|c|c|c|c|}
\hline Latent variables $^{a}$ & 1. & 2. & 3. & 4. & 5. & 6. & 7. & 8. \\
\hline 1. Coopetition & 0.75 & & & & & & & \\
\hline 2. Customer satisfaction performance & 0.06 & 0.76 & & & & & & \\
\hline 3. Market performance & 0.00 & 0.50 & 0.77 & & & & & \\
\hline 4. Financial performance & 0.00 & 0.38 & 0.46 & 0.78 & & & & \\
\hline 5. Firm size & 0.01 & 0.00 & 0.00 & 0.03 & N/A & & & \\
\hline 6. Firm age & 0.61 & 0.00 & 0.00 & 0.00 & 0.03 & N/A & & \\
\hline 7. Degree of internationalisation & 0.00 & 0.00 & 0.00 & 0.05 & 0.11 & 0.00 & N/A & \\
\hline 8. Regional competitiveness & 0.05 & 0.01 & 0.01 & 0.00 & 0.06 & 0.18 & 0.18 & N/A \\
\hline
\end{tabular}

Note: ${ }^{a}$ The off-diagonal values are the squared phi matrix correlations (accessed from LISREL 9.30). The diagonal values are the AVEs for the latent variables. As firm size, firm age, degree of internationalisation, and regional competitiveness were measured through single-indicators, their AVEs cannot be calculated. Since the multi-item scales produced high AVEs (greater than 0.50), the measures for the single-item constructs were assumed to have AVEs that exceeded the minimum benchmarks.

Table 6. Bivariate correlations

\begin{tabular}{|c|c|c|c|c|c|c|c|c|c|c|}
\hline Latent variables & Mean & SD & 1. & 2. & 3. & 4. & 5. & 6. & 7. & 8. \\
\hline 1. Coopetition & 4.85 & 0.92 & 1.00 & & & & & & & \\
\hline 2. Customer satisfaction performance & 5.16 & 1.00 & $0.23^{* \star \star}$ & 1.00 & & & & & & \\
\hline 3. Market performance & 5.46 & 1.01 & -0.01 & $0.66^{* * *}$ & 1.00 & & & & & \\
\hline 4. Financial performance & 4.03 & 0.98 & 0.04 & $0.57^{* * *}$ & $0.63^{* * *}$ & 1.00 & & & & \\
\hline 5. Firm size & 2.53 & 0.72 & -0.05 & -0.02 & 0.01 & 0.13 & 1.00 & & & \\
\hline 6. Firm age & 1.51 & 0.34 & $0.64^{* * *}$ & $0.17^{*}$ & 0.03 & -0.04 & $-0.17^{*}$ & 1.00 & & \\
\hline 7. Degree of internationalisation & 2.57 & 1.56 & -0.03 & -0.03 & 0.08 & $0.20^{* *}$ & $0.27^{* * *}$ & -0.06 & 1.00 & \\
\hline 8. Regional competitiveness & 4.11 & 0.84 & 0.14 & -0.09 & -0.09 & -0.02 & 0.16 & $0.28^{* \star \star}$ & 0.06 & 1.00 \\
\hline
\end{tabular}


Table 7. Hierarchical regression analysis

\begin{tabular}{|c|c|c|c|c|c|c|c|c|c|}
\hline & \multicolumn{3}{|c|}{ Model 1} & \multicolumn{3}{|c|}{ Model 2} & \multicolumn{3}{|c|}{ Model 3} \\
\hline Step 1: control paths ${ }^{a}$ & $\beta$ & $t$-values & Sig. & $\beta$ & $t$-values & Sig. & $\beta$ & $t$-values & Sig. \\
\hline Firm size & -0.01 & -0.06 & 0.95 & -0.03 & -0.24 & 0.81 & 0.07 & 0.66 & 0.51 \\
\hline Firm age & 0.21 & 2.01 & 0.05 & 0.07 & 0.63 & 0.53 & -0.01 & -0.07 & 0.95 \\
\hline Degree of internationalisation & -0.01 & -0.01 & 0.99 & 0.09 & 0.89 & 0.38 & 0.19 & 1.77 & 0.08 \\
\hline Regional competitiveness & -0.15 & -1.42 & 0.16 & -0.12 & -1.12 & 0.27 & -0.02 & -0.16 & 0.87 \\
\hline \multicolumn{10}{|l|}{ Model fit summary } \\
\hline $\mathrm{R}$ & 0.22 & & & 0.14 & & & 0.22 & & \\
\hline $\mathrm{R}^{2}$ & 0.04 & & & 0.02 & & & 0.04 & & \\
\hline Adjusted $\mathrm{R}^{2}$ & 0.01 & & & -0.02 & & & 0.01 & & \\
\hline \multicolumn{10}{|l|}{ Change statistics } \\
\hline$\Delta R^{2}$ & 0.04 & & & 0.02 & & & 0.04 & & \\
\hline$\Delta F$ & 1.24 & & & 0.49 & & & 1.19 & & \\
\hline Sig. & 0.30 & & & 0.45 & & & 0.32 & & \\
\hline Step 2: add main effect & $\beta$ & $t$-values & Sig. & $\beta$ & $t$-values & Sig. & $\beta$ & $t$-values & Sig. \\
\hline Firm size & -0.02 & -0.21 & 0.83 & -0.02 & -0.22 & 0.83 & 0.07 & 0.68 & 0.50 \\
\hline Firm age & 0.10 & 0.70 & 0.48 & 0.11 & 0.74 & 0.46 & -0.08 & -0.58 & 0.56 \\
\hline Degree of internationalisation & -0.01 & -0.04 & 0.97 & 0.09 & 0.87 & 0.39 & 0.19 & 1.79 & 0.08 \\
\hline Regional competitiveness & 0.05 & 0.43 & 0.67 & 0.01 & 0.12 & 0.90 & -0.06 & -0.56 & 0.57 \\
\hline Coopetition & 0.19 & 1.42 & 0.16 & -0.06 & -0.41 & 0.69 & 0.10 & 0.73 & 0.47 \\
\hline \multicolumn{10}{|l|}{ Model fit summary } \\
\hline $\mathrm{R}$ & 0.27 & & & 0.15 & & & 0.23 & & \\
\hline $\mathrm{R}^{2}$ & 0.07 & & & 0.02 & & & 0.05 & & \\
\hline Adjusted $\mathrm{R}^{2}$ & 0.02 & & & -0.03 & & & 0.00 & & \\
\hline & & & & & & & & & \\
\hline
\end{tabular}




\begin{tabular}{|c|c|c|c|c|c|c|c|c|c|}
\hline \multicolumn{10}{|l|}{ Change statistics } \\
\hline$\Delta R^{2}$ & 0.03 & & & 0.00 & & & 0.01 & & \\
\hline$\Delta F$ & 2.28 & & & 0.16 & & & 0.43 & & \\
\hline Sig. & 0.14 & & & 0.70 & & & 0.51 & & \\
\hline Step 3: add quadratic effect & $\beta$ & $t$-values & Sig. & $\beta$ & $t$-values & Sig. & $\beta$ & $t$-values & Sig. \\
\hline Firm size & -0.01 & -0.04 & 0.97 & -0.01 & -0.06 & 0.96 & 0.08 & 0.76 & 0.45 \\
\hline Firm age & 0.00 & 0.03 & 0.98 & -0.01 & -0.01 & 0.99 & -0.14 & -1.07 & 0.29 \\
\hline Degree of internationalisation & 0.01 & 0.11 & 0.92 & 0.11 & 1.08 & 0.28 & 0.20 & 1.94 & 0.06 \\
\hline Regional competitiveness & -0.10 & -1.00 & 0.32 & -0.07 & -0.68 & 0.50 & 0.03 & 0.26 & 0.80 \\
\hline Coopetition & 0.24 & 1.90 & 0.06 & 0.01 & 0.05 & 0.96 & 0.13 & 1.04 & 0.30 \\
\hline Coopetition (squared) & -0.26 & -2.58 & 0.01 & -0.33 & -3.28 & 0.00 & -0.26 & -2.61 & 0.01 \\
\hline \multicolumn{10}{|l|}{ Model fit summary } \\
\hline $\mathrm{R}$ & 0.37 & & & 0.35 & & & 0.34 & & \\
\hline $\mathrm{R}^{2}$ & 0.13 & & & 0.12 & & & 0.12 & & \\
\hline Adjusted $\mathrm{R}^{2}$ & 0.08 & & & 0.07 & & & 0.06 & & \\
\hline & \\
\hline $\begin{array}{l}\text { Change statistics } \\
\Delta R^{2}\end{array}$ & 0.06 & & & 0.10 & & & 0.07 & & \\
\hline$\Delta F$ & 6.66 & & & 10.73 & & & 6.82 & & \\
\hline Sig. & 0.01 & & & 0.00 & & & 0.01 & & \\
\hline \multicolumn{10}{|c|}{ 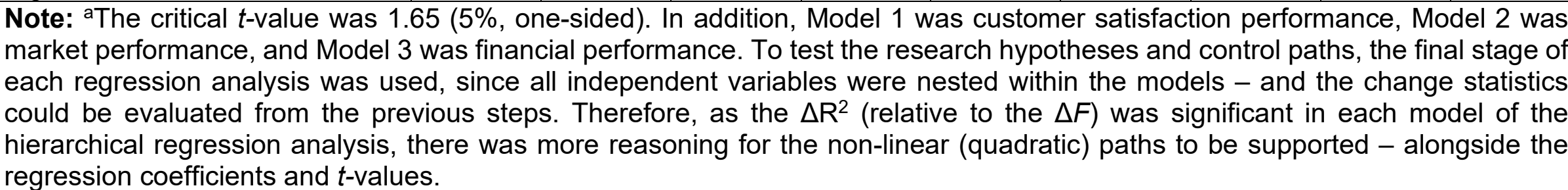 } \\
\hline
\end{tabular}




\section{Appendix 1. Full-list of the multi-item measurement scales}

\section{Coopetition}

In our organisation...

- COOP_1 - ... we collaborate with our competitors extensively

- COOP_2 - ... we share assets (e.g., equipment) with our competitors

- COOP_3 - ... we cooperate with our rivals to achieve a common goal

- COOP_4 - ... an active collaboration with rival firms is important to us

Anchors: 1 = very strongly disagree to 7 = very strongly agree (adapted from Bouncken and Kraus, 2013; Bouncken et al., 2018).

\section{Customer satisfaction performance}

Please evaluate the performance of your business over the past year (twelve months) relative to your major competitors:

- CUST_1-Customer satisfaction

- CUST_2 - Delivering value to your customers

- CUST_3 - Delivering what your customers want

- CUST_4 - Retaining valued customers

Anchors: $1=$ much worse than competitors to $7=$ much better than competitors (adapted Vorhies and Morgan, 2005).

\section{Market performance}

Please evaluate the performance of your business over the past year (twelve months) relative to your major competitors:

- MARK_1 - Market share growth

- MARK_2 - Growth in sales revenue

- MARK_3 - Acquiring new customers

- MARK_4 - Increasing sales from existing customers

Anchors: $1=$ much worse than competitors to $7=$ much better than competitors (adapted from Hooley et al., 2005).

\section{Financial performance}

Please evaluate the performance of your business over the past year (twelve months) relative to your major competitors:

- FINA_1 - Overall profitability

- FINA_2 - Return on investments (ROI)

- FINA_3 - Return on sales (ROS)

- FINA_4 - Return on assets (ROA)

- FINA_5 - Reaching financial goals

Anchors: $1=$ much worse than competitors to $7=$ much better than competitors (adapted from Morgan et al., 2009). 


\section{Informant quality}

In closing to the survey:

- INQ_1 - I am confident that my answers reflect my organisation's situation

- INQ_2 - This survey deals with issues I am very knowledgeable about

- INQ_3 - My role qualifies me as an appropriate person to complete this survey

Anchors: $1=$ very strongly disagree to $7=$ very strongly agree (adapted from Hultman et al., 2009). 